\title{
Singapur Sözleşmesi ve Uluslararası Ticari Arabuluculuk Sonucunda Ortaya Çıkan Sulh Anlaşmalarının Tanınması ve İcrası Meselesi
}

\author{
Singapore Convention and the Issue of Recognition and Enforcement \\ of Settlement Agreements Resulting from International Commercial \\ Mediation
}

Talat KAYA*ip

Öz

Sunduğu avantajlar ve kullanılma potansiyeline rağmen, arabuluculuk yöntemi uluslararası nitelikteki ticari uyuşmazlıkları çözmek için sıklıkla başvurulan bir yol değildir. Özellikle, tahkim yolu ile kıyaslandığında uluslararası ticari uyuşmazlıkların çözümünde arabuluculuk yönteminin çok az kullanıldığı görülmektedir. Uyuşmazlık taraflarının arabuluculuk yöntemine başvurmama sebeplerinin başında, süreç sonrasında varılan sulh anlaşmalarının icra kabiliyetinden yoksun olması gelmektedir. Bu bağlamda, BM Uluslararası Ticaret Hukuku Komisyonu (UNCITRAL) kapsamında hazırlanan Singapur Sözleşmesi, uluslararası ticari uyuşmazlıkların çözümü için arabuluculuğun teşvik edilmesini ve arabuluculuk süreci sonucunda taraflarca varılan sulh anlaşmalarının icrasının sağlanmasını amaçlamaktadır. 7 Ağustos 2019 tarihinde Türkiye’nin de dahil olduğu 46 ülke tarafından imzalanan Sözleşme’nin yakın zamanda yürürlüğe girmesi beklenmektedir.

Anahtar Kelimeler: Arabuluculuk, Singapur Sözleşmesi, Tanıma ve Tenfiz, New York Sözleşmesi, UNCITRAL

\begin{abstract}
Despite the advantages and potential of its use, mediation is not a commonly resorted method of resolving international commercial disputes. Especially, mediation is infrequently used in the resolution of international commercial disputes compared to the arbitration. Lack of enforceability of mediated settlement agreements is one of the main reasons why the parties to the dispute do not use mediation. In this regard, the Singapore Convention, developed under auspices of the UN Commission on International Trade Law (UNCITRAL), aims to promote mediation for the resolution of international commercial disputes and provide a framework for the enforcement of mediated settlement agreements. The Convention was signed by 46 countries, including Turkey, on August 7, 2019. It is expected that the Convention will enter into force very soon.

Keywords: Mediation, Singapore Convention, Recognition and Enforcement, New York Convention, UNCITRAL

* Dr. Öğr. Üyesi, Ankara Sosyal Bilimler Üniversitesi, Hukuk Fakültesi, Milletlerarası Özel Hukuk Anabilim Dalı, E-Mail: talat.kaya@asbu.edu.tr.
\end{abstract}




\section{GíRiş}

Anglo-sakson menşeli etkin bir alternatif uyuşmazlık çözüm yolu olan arabuluculuk yöntemi son 20 yılda Kıta Avrupası ülkeleri başta olmak üzere birçok ülkenin gündemine girmiş, ülkemiz de dahil olmak üzere pek çok ülke bu alanda düzenleme yapmıştır ${ }^{1}$. Nitekim, Avrupa Birliği (AB) içerisinde 1998 yllından itibaren önce alternatif uyuşmazlık çözüm yöntemlerinin geliştirilmesi tavsiye ve çağrılara konu olmuş, 2008 yılında kabul edilen Hukuki ve Ticari Uyuşmazlıklarda Arabuluculuğun Belirli Yönlerine İlişkin AB Parlamentosu ve Konseyi Direktifi ile de konu somut olarak düzenlenmiştir ${ }^{2}$. Arabuluculuk kültürüne çok da uzak olmayan Asya kıtasında ise başta Çin, Singapur ve Malezya olmak üzere pek çok ülke son yıllarda arabuluculuk konusunda yasal düzenlemeler kabul etmiştir ${ }^{3}$. Dünyadaki gelişim çizgisine paralel şekilde Türkiye de 2012 yılında Hukuk Uyuşmazlıklarında Arabuluculuk Kanununu (HUAK) kabul ederek, aslında yabancı olmadığı bir kültürü kurumsallaştırarak hukuk düzenine katmıştır ${ }^{4}$. Yine yakın zamanda kurulan İstanbul Tahkim Merkezi de uyuşmazlıkların arabuluculuk yoluyla çözümlenmesi için Arabuluculuk kuralları oluşturmuştur ${ }^{5}$.

Ulusal düzeyde yaşanan bu gelişmelere uluslararası gelişmeler eşlik etmiştir. Esasen, küreselleşmenin de etkisiyle ulusal ve uluslararası düzeyde yaşanan gelişmeler hem birbirini tetiklemiş hem de birbirinden etkilenmiştir. Bu kapsamda, uluslararası nitelikli uyuşmazlıkların çözümü için arabuluculuk kurumunun daha yaygın olarak kullanılması birçok uluslararası örgüt tarafından desteklenmiş, hatta daha çok uluslararası tahkim alanında hizmet veren ve bu konuda köklü bir geçmişi olan Milletlerarası Ticaret Odası (ICC), Çin Uluslararası Ekonomik ve Ticaret Tahkim Komisyonu (CIETAC) ve Dünya Fikri Mülkiyet Örgütü (WIPO) gibi kuruluşlar arabuluculuğa ilişkin kurallar kabul etmişlerdir 6 . Keza arabuluculuk yönteminin yatırım

1 Tanrıver S., Hukuk Uyuşmazlıkları Bağlamında Alternatif Uyuşmazlık Çözüm Yolları ve Özellikle Arabuluculuk, TBB Dergisi, 2006, Sayı 64, s. 151 (Arabuluculuk). Esasen, arabuluculuk yöntemi son yirmi yılda ortaya çıkmış yeni bir uyuşmazlık çözüm yolu değildir. Arabuluculuk insanlık tarihi kadar eskidir ve geleneksel arabuluculuğun geçmişi eski çağlara kadar uzanır. Bu konuda daha detaylı bilgi için Bkz. Özbek M. S., Alternatif Uyuşmazlık Çözüm Yolu, 2. Baskı, Yetkin Yayınları, 2016, s. 632 vd. (Alternatif Uyuşmazlık Çözüm Yolu). Arabuluculuk yöntemi yakın dönemde de özellikle 20’nci yüzyılın başlarında uluslararası ticari uyuşmazlıkların çözümü amacıyla sıklıkla kullanılmıştır. İkinci Dünya Savaşı sonrasında ise tahkim yöntemi ön plana çıkmış, uluslararası ticari uyuşmazlıkların çözümü için neredeyse tek yol olarak görülmeye başlanmıştır. Bu bağlamda, arabuluculuk yönteminin son yirmi yılda uyuşmazlıkları çözmek için kullanılmaya başlanması, gerçekte unutulan bir çözüm yolunun modernleştirilerek yeniden hatırlanmasıdır. Bkz. Strong, S. I., Beyond International Commercial Arbitration? The Promise of International Commercial Mediation, 45 Washington University Journal of Law and Policy, 2014, s. 11-12.

2 https://eur-lex.europa.eu/LexUriServ/LexUriServ.do?uri=OJ:L:2008:136:0003:0008:EN:PDF, son erişim tarihi 27 Eylül 2019.

3 Chua E., The Singapore Convention on Mediation - A Brighter Future for Asian Dispute Resolution, Asian Journal of International Law, 2019, s. 203-204.

4 Özekes M., Pekcanıtez Usul Medeni Usul Hukuku, 15. Bası, İstanbul, 2017, s. 2808.

5 İstanbul Tahkim Merkezi (İSTAC) Tahkim ve Arabuluculuk Kuralları için Bkz. https://istac.org.tr/wp-content/ uploads/2016/01/ISTANBUL-TAHKIM-MERKEZİ-TAHKİM-ve-ARABULUCULUK-KURALLARI.pdf, son erişim tarihi 10 Ekim 2019.

6 Öztürk, N., Arabuluculuğun Milletlerarası Özel Hukuk Boyutu: Genel Bakış, Banka ve Ticaret Hukuku Dergisi, Cilt: 31, Sayı: 2, 2015, s. 217; Vanisova V., Current Issues in International Commercial Mediation: Short Note on the Nature of Agreement Resulting from Mediation in the Light of the Singapore Convention, Charles University in 
uyuşmazlıkları bakımından da kullanılmasını teminen Uluslararası Yatırım Uyuşmazlıkları Çözüm Merkezi (ICSID) tarafından 1979 yılında uzlaştırma kuralları yayınlanmış, 2018 yılında başlatılan çalışma sonucunda ise taslak arabuluculuk kuralları oluşturulmuştur. Arabuluculuğa ilişkin söz konusu kuralların yakın zamanda kabul edilmesi beklenmektedir ${ }^{7}$

Uluslararası ticaret hukuku alanında üye ülkelerde mevzuat çalışmalarını kolaylaştırmak, var olanların ise modernleştirmelerine yardımcı olmak üzere BM çatısı altında faaliyet gösteren Birleşmiş Milletler Uluslararası Ticaret Hukuku Komisyonu (UNCITRAL) da arabuluculuk konusunda ulusal ve uluslararası düzeyde yaşanan gelişmelere kayıtsız kalmamıştır. Bu bağlamda UNCITRAL 2002 yılında Uluslararası Ticari Arabuluculuk Model Kanununu (Model Kanun) kabul etmiştir. Bununla birlikte, uluslararası arabuluculuk süreci sonucunda varılan sulh anlaşmalarının, hakem kararları gibi icra edilmelerini sağlayacak bir mekanizmanın olmayışı, arabuluculuk sürecinin uluslararası uyuşmazlıklar bakımından kullanımını kısıtlamıştır ${ }^{8}$. Bu çerçevede, 2014 yılında Amerika Birleşik Devletleri’nin (ABD) girişimi ile UNCITRAL bünyesinde uluslararası ticari arabuluculuk süreci sonrasında varılan sulh anlaşmalarına hakem kararlarına benzer bir statü tanınmasına yönelik bir çalışma başlatılmıştır ${ }^{9}$. Söz konusu çalışma sonrasında 2018 yılında, bir yandan UNCITRAL Model Kanunu ${ }^{10}$ sulh anlaşmalarının icrasına yönelik hükümleri içerecek şekilde güncellenmiş, diğer yandan Arabuluculuk Sonucunda Yapılan Uluslararası Sulh Anlaşmaları Hakkındaki Birleşmiş Milletler Sözleşmesi (Singapur Sözleşmesi)

Prague Faculty of Law Research Paper No. 2019/II/5, 2019, s. 2, https://ssrn.com/abstract=3413560 or http://dx.doi. org/10.2139/ssrn.3413560, son erişim tarihi 16 Ağustos 2019; İlgili kuruluşların arabuluculuk karar ve usulleri için sırasiyla Bkz. https://iccwbo.org/dispute-resolution-services/mediation/mediation-rules/; http://www.cietac.org/ index.php? $\mathrm{m}=$ Article\&a=show\&id=15889\&l=en ; https://www.wipo.int/amc/en/mediation /rules/ son erişim tarihi 2 Ekim 2019;

7 Söz konusu kuralların son hali için Bkz. Proposals For Amendment Of The ICSID Rules, Working Paper \#3, Volume 1 English August 2019, s. 208 vd. https://icsid.worldbank.org/en/Documents/WP_3_VOLUME_1_ENGLISH.pdf, son erişim tarihi 3 Ekim 2019.

8 Strong, s. 28; Sussman E., The Singapore Convention Promoting the Enforcement and Recognition of International Mediated Settlement Agreements, ICC Dispute Resolution Bulletin, Issue 3, 2018, s. 42; Öte yandan, Uluslararası Arabuluculuk Enstitüsü (IMI) tarafından 2016-2017 yılları arasında Küresel Pound Konferansları (Global Pound Conference-GPC) kapsamında uluslararası ölçekte yapılan araştırmada katılımcıların büyük bir kısmı arabuluculuk yöntemi sonucunda varılan anlaşmalar da dahil olmak üzere, taraflar arasında varılan anlaşmaların tanınması ve tenfizini sağlayacak mevzuat ve uluslararası sözleşmelerin uluslararası ticari uyuşmazlıkların çözümünü kolaylaştıracağını belirtmişlerdir. Söz konusu araştırmaların detayları için Bkz. International Mediation Institute, GPC Series 'Cumulated Data Results, https://www.globalpound.org/wp-content/uploads/2017/11/2017-09-18Final-GPC-Series-Results-Cumulated-Votes-from-the-GPC-App-Mar-2016-Sep.-2017.pdf son erişim tarihi 3 Ekim 2019.

9 Abramson H., New Singapore Convention on Cross-Border Mediated Settlements: Key Choices, Mediation in International Commercial and Investment Disputes, Eds. Titi C./ FachGomez K., Oxford University Press, 2019, s. 362; Claxton J., The Singapore Convention: Mediation in a New York State of Mind, https://ssrn.com/abstract=3416116, s. 1 ; Sussman, s. 42.

10 UNCITRAL Model Law on International Commercial Mediation and International Settlement Agreements Resulting from Mediation, 2018 (amending the UNCITRAL Model Law on International Commercial Conciliation, 2002), https://www.uncitral.org/pdf/english/commissionsessions/51st-session/Annex_II.pdf son erişim tarihi 8 Ekim 2019. 
kabul edilmiştir ${ }^{11}$. 7 Ağustos 2019 tarihinde Türkiye’nin de dahil olduğu 46 ülke ${ }^{12}$ tarafından imzalanan Singapur Sözleşmesi 1958 tarihli Yabancı Hakem Kararlarının Tanınması ve Tenfizi Hakkındaki New York Sözleşmesi’ni (New York Sözleşmesi) örnek almıştır. Sözleşme, temel olarak ticari arabuluculuk sonucunda varılan uluslararası sulh anlaşmalarının taraf Devletlerce icrasını ve açılmış bir davada kesin delil niteliğinde savunma amaçlı olarak kullanılmasını öngörmektedir ${ }^{13}$. Sulh anlaşmalarına icra edilebilirlik ve kesin delil vasıflarının tanınması New York Sözleşmesi’nde yer verilen tanıma ve tenfiz kavramlarından hareketle oluşturulmuştur. Bununla birlikte aralarında önemli farklılıklar bulunmaktadır.

$\mathrm{Bu}$ inceleme, ülkemiz ve tüm dünya bakımından çok yeni bir düzenleme olan Singapur Sözleşmesi hakkında bilgi vermeyi, örnek aldığı New York Sözleşmesi’nden farkını açıklamayı ve Sözleşme uyarınca arabuluculuk sonucunda oluşan sulh anlaşmalarına icra edilebilirlik vasfı tanınmasına ilişkin usulü incelemeyi amaçlamaktadır. Bu çerçevede çalışma beş bölüme ayrılmıştır. İlk bölümde Singapur Sözleşmesi’ne duyulan ihtiyacın nedenleri incelenecektir. İkinci bölümde Singapur Sözleşmesi’nin New York Sözleşmesi’nden temel farkları ve terim sorunu ele alınacaktır. Üçüncü bölümde Singapur Sözleşmesi'nin kapsamı açıklanacaktır. Dördüncü bölümde arabuluculuk sonucunda oluşan sulh anlaşmalarının tanınması ve icra edilebilirliği konusu incelenecektir. Beşinci bölüm Singapur Sözleşmesi’nin yürürlüğe girmesi ve Sözleşme’nin uygulanmaması amacıyla konulabilecek çekince meselelerine ayrılacaktır. Çalışmanın sonuç bölümünde, önceki bölümlerde ele alınan hususlar temelinde Singapur Sözleşmesi’nin Türkiye bakımından onaylanması konusundaki kanaatimiz ortaya konacaktır ${ }^{14}$.

11 UNCITRAL tarafından tanıma ve icra edilebilirlik konusunun hem Model Kanun'a dahil edilmesi hem de konuyla ilgili olarak Singapur Sözleşmesi’nin hazırlanması, üye ülkelere esneklik sağlamaya yöneliktir. Bu bağlamda, arabuluculuk yöntemine yabancı olan ülkelerin uluslararası bir yükümlülük altına girmeden Model Kanun yoluyla tanıma ve icra edilebilirlik konuları ile tanışmaları amaçlanmış iken, arabuluculuğu bir uyuşmazlık çözüm yolu olarak benimsemiş ülkeler bakımından arabuluculuk sonucunda oluşan sulh anlaşmalarının uluslararası seviyede tanınmaları ve icra edilmelerini sağlamak üzere Singapur Sözleşmesi kabul edilmiştir. Bu husus Singapur Sözleşmesi'ni kabul eden BM Genel Kurul Kararı́na da yansımıştır. United Nations General Assembly, A/ RES/73/198, para 5. https://undocs.org/en/A/res/73/198 son erişim tarihi 3 Ekim 2019. Bu çalışmanın konusunun Singapur Sözleşmesi’ne münhasır olması nedeniyle Model Kanun ayrıca inceleme konusu yapılmayacaktır.

1230 Eylül 2019 tarihi itibariyle 6 ülke daha Singapur Sözleşmesi’ni imzalamış ve böylelikle imzacı ülke sayısı 51'e ulaşmıştır. UNCITRAL Press Release, Treaty event produces new signatories for the United Nations "Singapore Convention on Mediation", http://www.unis.unvienna.org/unis/en/pressrels/2019/unisl282.html son erişim tarihi 3 Ekim 2019.

13 Singapur Sözleşmesi sulh anlaşmasının taraflarını belli etmek için "the party” veya "parties” kelimelerini kullanmıştır. Bu inceleme içerisinde bu kavramların Türkçe karşılığı olarak "taraf” ve "taraflar" ifadesi tercih edilmiştir. Singapur Sözleşmesi, Sözleşme’nin tarafı olan ülkeler için ise "the Party” veya "Parties” ifadelerini kullanmıştır. Sözleşmedeki kullanıma uygun olarak bu incelemede Sözleşme tarafı ülkelerin söz konusu olduğu hallerde "taraf Devlet” veya "taraf Devletler" ifadeleri kullanılmıştır.

14 Öte yandan, başta yetkili ve görevli mahkeme, yargılama usulü ve kanun yolları olmak üzere, Singapur Sözleşmesi’nin HUAK, Milletlerarası Özel Hukuk ve Usul Hukuku Hakkında Kanun (MÖHUK) ve Hukuk Muhakemeleri Kanunu’nu (HMK) içerecek şekilde Türk mevzuatı ile ilişkisi ve etkileşimi önemli görülmekle birlikte, bu incelemenin amacı ve bu konuların yeni bir makale konusu olacak şekilde hacimli olması göz önüne alınarak, bu çalışmada bu hususlar üzerinde durulmayacaktır. Araştırmamızın zikredilen konularda dahil olmak üzere yeni çalışmalara kapı aralaması umut edilmektedir. 


\section{Singapur Sözleşmesi'ne Duyulan İhtiyacın Nedenleri}

Arabuluculuk süreci sonucunda taraflar arasında varılan anlaşma birçok yönüyle, mahkeme ve tahkim yoluyla varılan çözümlere göre avantajlıdır. Zaman ve emek tasarrufu, maliyet avantajı, sulh anlaşmalarının taraf iradelerini yansıtması ve taraf menfaatlerine en uygun çözümü sunması söz konusu üstünlüklerin başında gelir ${ }^{15}$. Bu nedenle, pek çok ülkede arabuluculuk başta olmak üzere alternatif uyuşmazlık çözüm yollarına büyük bir yönelim başlamış, yabancı unsurlu uyuşmazlıklar da dahil olmak üzere, uyuşmazlıkların arabuluculuk yöntemi ile çözülmesi teşvik edilmiş, hatta bazı uyuşmazlıklar bakımından bu yönteme başvurulması dava şartı haline getirilmiştir ${ }^{16}$. Arabuluculuğun bir uyuşmazlık çözüm yöntemi olarak daha fazla kullanılmasını sağlamak bakımından ulusal hukuk düzenleri tarafından alınan en önemli tedbirlerden bir tanesi arabuluculuk süreci sonucunda varılan anlaşmalara icra edilebilirlik vasfını kazandırmak olmuştur. Nitekim, ülkemiz uygulamasında HUAK’nn 18(2)'nci maddesi uyarınca “taraflar arabuluculuk faaliyeti sonunda bir anlaşmaya varırlarsa, bu anlaşma belgesinin icra edilebilirliğine ilişkin şerh verilmesini talep edebilirler."

Uluslararası uyuşmazlıklar bakımından ise taraflardan birisinin sulh anlaşmasının gereklerini yerine getirmemesi durumunda, diğer taraf ya ulusal mahkemelerde sözleşmenin ihlaline dayanan bir dava açmak durumunda kalacak ya da taraflarca kararlaştırılmış ise tahkim yoluna başvurabilecektir ${ }^{17}$. Bu durum, arabuluculuğa başvurmadan önceki statüye geri dönme anlamına gelmektedir $^{18}$. Oysaki uluslararası ticari uyuşmazlıkların tarafları açısından, icra edilebilirlik belirli bir uyuşmazlık çözüm yöntemine başvurma açısından vazgeçilmezdir ${ }^{19}$. Bu bağlamda milletlerarası tahkimin avantajları sayılırken bu husus öne çıkarılmakta, arabuluculuk ve diğer alternatif çözüm yollarının icra kabiliyetinden yoksun olduğu vurgulanmaktadır ${ }^{20}$.

$\mathrm{Bu}$ çerçevede, arabuluculuk yoluyla uluslararası ticari uyuşmazlıkları çözen sulh anlaşmalarına icra kabiliyeti kazandırmak Singapur Sözleşmesi’nin kabul edilmesinin en temel nedenidir. Sözleşme arabuluculuk süreci sonucunda taraflarca varılan anlaşmanın basit ve düzenlenmiş bir usul uyarınca bağlayıcı ve uygulanabilir olmasını amaçlamıştır. Bu yolla bir yandan uluslararası

15 Özbek (Alternatif Uyuşmazlık Çözüm Yolu), s. 596; Özekes M, Pekcanıtez Usul, s. 2823; Öztürk, s. 205-206; Vanisova, s.4.

16 Bu bağlamda örneğin, Türkiye’de 2012 yılında HUAK’’n kabul edilmesi sonrasında, uygulamada sağlanan başarı nedeniyle, İş Mahkemeleri Kanunu m.3 ve Türk Ticaret Kanunu m. 5/A hükümleri ile bazı tür iş ve ticaret uyuşmazlıklarının çözümü için arabuluculuk yöntemine başvurulması dava şartı haline getirilmiştir. Öte yandan, dünyada ve ülkemizde aile hukuku uyuşmazlıkları da dahil olmak üzere arabuluculuk yolu ile çözümlenebilen uyuşmazlıkların kapsamının giderek genişletilmesi yolunda bir eğilim vardır. Konuyla ilgili olarak daha detaylı bilgi için Bkz. Güllüoğlu Altun Y., Aile Arabuluculuğu (Sisteme Genel Bakış), Prof Dr. Hüseyin Hatemi’ye 80. Yıl Armağanı, Edt. Güllüoğlu Altun Y, Onikilevha Yayınları, 2018, s. 477-514.

17 Akıncı, Milletlerarası Tahkim, Genişletilmiş ve Güncellenmiş 4. Baskı, Vedat Kitapçılık, 2016, s. 7; Hioureas C. G., The Singapore Convention on International Settlement Agreements Resulting from Mediation: A New Way Forward?, 37 Berkeley J. Int'l Law, 2019, s. 217; Vanisova, s. 5.

18 Schnabel T.,The Singapore Convention on Mediation: A Framework for the Cross-Border Recognition and Enforcement of Mediated Settlements, 19Pepp. Disp. Resol. L.J.1, 2019, s. 2-3.

19 Şanlı, s. 435.

20 Akıncl, s. 7. 
ticaretin gelişimi ve kolaylaştırılması, diğer yandan da uluslararası ticari uyuşmazlıkların arabuluculuk yoluyla çözülmesinin teşvik edilmesi hedeflenmiştir. Diğer bir anlatımla, Sözleşme ile arabuluculuk süreci sonucunda ortaya çıkan sulh anlaşmalarına uluslararası hakem kararlarının sahip olduğu statüye benzer bir statü tanınmak istenmiştir ${ }^{21}$.

\section{Singapur Sözleşmesi'nin New York Sözleşmesi'nden Temel Farkları ve Terim Sorunu}

Arabuluculuk sonucunda varılan sulh anlaşmalarına uluslararası bir hukuki vasıf kazandırma amacıyla yapılan Singapur Sözleşmesi esas itibariyle, yabancı hakem kararlarının tanınması ve tenfizini öngören New York Sözleşmesi’nin takip ettiği sistematiği kendisine örnek almıştır ${ }^{22}$. Bu bağlamda, iki sözleşme arasındaki benzerlik büyüktür. Aşağıda inceleneceği üzere, Singapur Sözleşmesi arabuluculuk süreci sonucunda oluşan anlaşmaların tanınması ve icra edilebilirliği taleplerinin reddi sebeplerini büyük oranda New York Sözleşmesi’ni esas alarak düzenlemiştir. İki sözleşme arasındaki benzerliklere Sözleşme’nin içeriğinin ele alındığı aşağıdaki bölümlerde yeri geldiğince değinilecektir. Bu başlık altında ise kullanılan terimler başta olmak üzere iki sözleşme arasındaki önem arz eden farklılıklar açıklanacaktır.

İlk olarak Singapur Sözleşmesi New York Sözleşmesi'nin aksine tarafların arabuluculuğa başvurma konusunda yaptıkları sözleşmeyle ilgilenmemektedir. New York Sözleşmesi kapsamında tahkime başvurma konusunda taraflar arasında yapılan tahkim sözleşmesi tanıma ve tenfiz aşamasında önemli bir fonksiyona sahiptir. Nitekim tanıma ve tenfiz aşamasında talepte bulunan taraf tahkim sözleşmesini yetkili makama sunmak zorundadır. Ayrıca tahkim sözleşmesinin tabi olduğu hukuka göre geçersiz olması, hakem kararının tanınması ve tenfizine engel bir hal olarak sayılmıştır. Singapur Sözleşmesi kapsamında ise arabuluculuğa başvurma konusunda taraflar arasında bir sözleşme olmasa, sözleşme geçersiz olsa dahi tarafların sonradan arabuluculuğa başvurmaları ve nihayetinde bir anlaşmaya varmaları durumunda bu anlaşma geçerli sayılacak ve icra edilebilirlik talebine konu edilebilecektir. Diğer bir anlatımla, Singapur Sözleşmesi arabuluculuğa başvurma aşamasıyla ilgilenmemekte, süreç sonrasında ortaya çıkan sulh anlaşmasını esas almaktadır ${ }^{23}$. Arabuluculuk açısından bu anlayış kanaatimizce de doğrudur. Zira, taraf iradelerinin birinci derecede rol oynadığı arabuluculuk süreci içerisinde tarafların sulh anlaşmasına ilişkin iradelerinin, otomatik olarak arabuluculuğa başvurma konusundaki irade uyuşmasını da kapsadığını değerlendirmekteyiz.

İkinci olarak, Singapur Sözleşmesi arabuluculuk sonucunda varılan anlaşmaların tanınması ve tenfizini sağlama gayesiyle yola çıkmış olmakla birlikte, Sözleşmenin müzakereleri esnasında yaşanan tartışmalar ve ortaya çıkan metin, sulh anlaşmalarının mahkeme ve hakem kararları

21 Chong S./ Steffek F., Enforcement of International Settlement Agreements Resulting From Mediation Under The Singapore Convention - Private International Law Issues in Perspective, Singapore Academy of Law Journal. 31, (Special Issue), 2019, s. 450-451; Hioureas, s. 219; Sussman, s. 43.

22 Chua, s. 195; Sussman, s. 48.

23 Claxton, s. 4; Sussman, s. 49. 
gibi, onlara eşdeğer şekilde, tanınması ve tenfizinin mümkün olmayacağını göstermiştir. Zira arabuluculuk süreci sonucunda ortaya çıkan sulh anlaşmalarına tanınan gerçeklik niteliği (kanuni hakikat vasfi) mahkeme ve hakem kararlarından farklıdır. Bu farklılık temel olarak, sulh anlaşmalarının, mahkeme ve hakem kararlarının aksine kesin hüküm (res judicata) vasfına sahip olmamasından kaynaklanmaktadır ${ }^{24}$. Nitekim, Sözleşme’nin müzakereleri sırasında tanımanın hukuki mahiyeti ve bu bağlamda özellikle kesin hüküm etkisinin olup olmadı̆̆ı konusunda ciddi tartışmalar yaşanmıştır ${ }^{25}$. Yapılan tartışmalar neticesinde ortak bir anlayışa ulaşılamaması nedeniyle, Singapur Sözleşmesi kapsamında tanıma ve tenfizden ne murat edildiği "genel ilkeler” başlıklı 3’üncü maddede açıklanmıştır. Söz konusu hüküm Singapur Sözleşmesi ile sulh anlaşmalarına tanınan vasıfların New York Sözleşmesi ile hakem kararlarına bahşedilen tanıma ve tenfiz edilebilme vasıflarının önemli bir kısmını içerdiğini göstermektedir.

Bu bağlamda, Sözleşme’nin 3'üncü maddesinin ilk fikrası “her taraf Devlet kendi usul kuralları ve Sözleşmede öngörülen şartlar temelinde arabuluculuk süreci sonucunda varılan anlaşmaları icra edecektir" ifadesini içermektedir ${ }^{26}$. Sözleşme arabuluculuk sonucunda varılan sulh anlaşmalarının icrası konusunda özel bir yöntem öngörmemiş, icranın nasıl yapılacağ ülkeye bırakmıştır. Uygulamada anlaşmaların icrası için bazı ülkelerde doğrudan icra merciine başvurulabilecekken, diğer bazı ülkelerde mahkemeden alınacak bir karar sonrasında icra mümkün olabilecektir ${ }^{27}$. Esasen Singapur Sözleşmesi bu konuda, yabancı hakem kararlarının tanınması ve tenfizi hakkındaki New York Sözleşmesi ile benimsenen yaklaşımı takip etmiştir ${ }^{28}$.

5718 sayılı MÖHUK ve New York Sözleşmesi kapsamında, ülkemiz uygulaması bakımından yabancı hakem kararlarının icrası ancak yetkili mahkemeden alınacak bir tenfiz kararı ile mümkündür. Öte yandan, yabancı unsurlu uyuşmazlıklara ilişkin olanlar da dahil olmak üzere, arabuluculuk sonucunda oluşan anlaşma belgelerinin icra edilebilirlik vasfı kazanması ise HUAK’ın 18'inci maddesi kapsamında kural olarak yetkili mahkemeden alınacak bir icra edilebilirlik şerhi ile mümkün olmaktadır²9. Tüm bu hususlar, ülkemiz uygulaması bakımından uluslararası nitelikli

24 Milletlerarası Özel Hukuk bağlamında mahkeme kararlarının kesin hüküm ve kesin delil etkisi konusunda Bkz. Arat T., Yabancı İlamların Tanınması ve Tenfizi, AÜHFD, Cilt 21 Sayı 1-4, 1964, s. 424-425; Can H./ Tuna E., Milletlerarası Usul Hukuku, 2. Baskı, Adalet Yayınevi, 2019; s. 317-318; Çelikel A./ Erdem B. B., Milletlerarası Özel Hukuk, 15. Baskı, Beta Yayınları 2017, s.680-684; Sargın, F./Erten, R., MÖHUK Hükümleri Dairesinde Tanımanın Hukuki Niteliği, Usûlü ve Karşılaşılan Bazı Sorunlar: Yeni Bir Düzenleme Yapma Gereği, Uluslararası Ticaret ve Tahkim Hukuku Dergisi, İstanbul 2014, C.3, S.2, s. 46-52; Şanlı C./ Esen E./ Ataman-Figanmeşe İ., s. 526-532; Özkan I./ Tütüncübaşı U., Uluslararası Usul Hukuku, Adalet Yayınevi, 2017, s. 181-187; Yabancı hakem kararlarının kesin hüküm ve kesin delil etkisi konusunda ise bkz. Akıncı, s. 335-337;Can/Tuna, s. 318-319.

Schnabel, s. 35-36; Sussman, s. 49.

Singapur Sözleşmesi m. 3(1)'de yer alan İngilizce orijinal ifade ise şu şekildedir: "Each Party to the Convention shall enforce a settlement agreement in accordance with its rules of procedure and under the conditions laid down in this Convention".

Özdemir, s. 239-240.

Chua, s. 197; Schnabel, s. 39; Aynı konuyu elen New York Sözleşmesi m. III’de yer alan İnglizce orijinal ifadenin ilgili kısmı şu şekildedir: "Each Contracting State shall recognize arbitral awards as binding and enforce them in accordance with the rules of procedure of the territory where the award is relied upon, under the conditions laid down in the following articles...".

HUAK'ın 18'inci maddesine 2017 yllında eklenen yeni bir fikra “Taraflar ve avukatları ile arabulucunun birlikte 
sulh anlaşmalarına icra edilebilirlik kabiliyetinin yetkili mahkeme tarafından verilecek bir "icra edilebilirlik kararı"30 sonrasında sağlanabileceğini göstermektedir. Bununla birlikte, kanaatimizce icra edilebilirlik kararı sulh anlaşmalarına maddi anlamda kesin hüküm vasfı vermeyecek, sadece icra edilebilmelerini sağlayacaktır. Türk hukuku bakımından icra edilebilirlik kararı, HUAK kapsamına giren taraf anlaşmalarına verilen “icra edilebilirlik şerhi” ile aynı etkiyi doğuracaktır ${ }^{31}$. Nitekim HUAK'ın 18(2)'nci maddesi uyarınca taraflar arasında varılan anlaşmaya icra edilebilirlik şerhinin verilmesiyle anlaşma ilam niteliğinde belge hüviyetini kazanır ${ }^{32}$. Bununla birlikte icra edilebilirlik şerhi anlaşmayı maddi anlamda kesin hüküm haline getirmez, sadece icra edilebilirlik açısından ilamlar ile aynı hukuki rejime tabi tutulmasını sağlar ${ }^{33}$. Bu yolla anlaşma gereklerinin bir tarafça yerine getirilmemesi halinde diğer tarafa cebri icraya başvurma imkanı verilmektedir.

Sözleşme’nin 3'üncü maddesinin ikinci fikrası ise, arabuluculuk sonucunda varılan sulh anlaşmasına rağmen, taraflardan birinin yargı yoluna başvurması halinde, sulh anlaşmasının bu davada nasıl ele alınacağına ilişkin ilkeleri ortaya koymaktadır. Müzakereler sırasında tanımanın hukuki mahiyeti ve "kesin hüküm” etkisinin olup olmadığı konusundaki ortaya çıkan tartışmalar aynı zamanda Sözleşme kapsamında tanımaya ihtiyaç olduğunu göstermiştir ${ }^{34}$. Tartışmalar neticesinde farklı hukuk sistemlerinde farklı anlamlar ifade eden "tanıma" ifadesinin bizatihi kendisinin Sözleşme içerisinde kullanılmaması konusunda uzlaşmaya varılmıştır ${ }^{35}$. Karşılığında ise "tanıma"nın Sözleşme kapsamına alınmak istenen bölümünün, fonksiyonel eşitlik yöntemi kullanılarak uzun bir betimlemeyle ${ }^{36}$ Sözleşme kapsamına dahil edilmesi kararlaştırılmıştır ${ }^{37}$.

imzaladıkları anlaşma belgesi, icra edilebilirlik şerhi aranmaksızın ilam niteliğinde belge sayıltr." hükmünü içermektedir. Bu bağlamda taraflar ve avukatları ile arabulucunun birlikte imzaladıkları anlaşma belgesinin cebri icrası için mahkemeden ayrıca "icra edilebilirlik şerhi" alınmasına gerek yoktur.

30 "İcra edilebilirlik kararı" ifadesi yerine "tenfiz kararı" ifadesinin kullanılması da düşünülmüş olmakla birlikte, yabancı mahkeme ve hakem kararlarının tenfizi ifadesinin aynı zamanda söz konusu kararların "kesin hüküm" etkisinin tanınmasını da içermesi nedeniyle, kavram kargaşasına meydan vermemek adına "icra edilebilirlik kararı" ifadesi tercih edilmiștir. Ayrıca, HUAK'da kullanılan “icra edilebilirlik şerhi” ifadesi ile de tutarlılık sağlanması amaçlanmıştır.

31 Türk Hukuku bakımından arabuluculuk sonucunda varılan anlaşmalar HUAK'ın 18'inci maddesi uyarınca icra edilebilirlik şerhi alsalar ve ilam niteliğinde belge olarak sayılsalar dahi Hukuk Muhakemeleri Kanunu (HMK) 388. maddesi uyarınca maddi anlamda "kesin hüküm" teșkil etmezler.

32 Özbek, M. S., Arabuluculuk Sonunda Düzenlenen Anlaşma Belgesine İcra Edilebilirlik Şerhi Verilmesinde Görevli ve Yetkili Mahkeme, Başkent Üniversitesi Hukuk Fakültesi Dergisi, Cilt: 3, Sayı: 2, 2017, s. 75 (İcra Edilebilirlik).

33 Özbek (İcra Edilebilirlik), s. 75.

34 Sussman, s. 49.

35 Sussman, s. 49.

36 Singapur Sözleşmesi m. 3(2)'de yer alan İngilizce orijinal ifade ise şu şekildedir. "If a dispute arises concerning a matter that a party claims was already resolved by a settlement agreement, a Party to the Convention shall allow the party to invoke the settlement agreement in accordance with its rules of procedure and under the conditions laid down in this Convention, in order to prove that the matter has already been resolved."; Söz konusu betimlemenin Özsunay tarafından yapılan çevirisi şu şekildedir: "Eğer bir uyuşmazlık bir tarafin bir sulh sözleşmesiyle çözüme bağlanmış olduğunu iddia ettiği bir konuya ilişkin bulunuyorsa "Sözleşmeye taraf olan Devlet" (the Party to the Convention); kendi usul hukuku kuralları uyarınca ve işbu Sözleşmede öngörülen koşullar altında, söz konusu tarafa sorunun esasen halledilmiş olduğunun kanıtlanması için sulh anlaşmasına başvurmasına izin verir." Özsunay E. "Arabuluculuk Sonucunda Yapılan Uluslararası Sulh Anlaşmaları Hakkında Birleşmiş Milletler Sözleşmesi”: Singapur Arabuluculuk Sözleşmesi Türk Hukukuyla Uyumu Bakımından Bir Değerlendirme, İstanbul Barosu Dergisi, Cilt: 93, Sayı: 3, 2019, s. 38. 
Sözleşme’nin 3’üncü maddesinin ikinci fıkrası hükmüne göre arabuluculuk süreci sonucunda varılan anlaşma ile çözülen bir mesele ile ilgili taraflar arasında yeni bir uyuşmazlığın çıkması halinde, Sözleşmeye taraf Devlet; kendi usul kuralları ve Sözleşme’de öngörülen şartlar temelinde, anlaşmanın diğer tarafına söz konusu meselenin daha önce çözülmüş olduğunu ispat için anlaşmayı öne sürme imkanı tanıyacaktır.

Sözleşme’nin müzakereleri sırasında ortaya çıkan tartışmalar da göz önüne alınarak, betimleme ile amaçlananın arabuluculuk süreci sonucunda varılan anlaşmalara mahkeme veya hakem kararları gibi "kesin hüküm” kuvveti tanımak olmadığını düşünmekteyiz. Buradaki maksadın, sulh anlaşmasının tarafları arasında aynı konuda ve aynı sebebe dayanarak açılmış bir davada; sulh anlaşmasının "kesin delil” niteliğinin tanınması olduğunu değerlendirmekteyiz ${ }^{38}$. Bu bağlamda, esas olarak arabuluculuk süreci sonucunda ortaya çıkan anlaşmalara hakem kararları gibi "kesin hüküm” kuvveti tanınması istenmemiş, ancak sıradan bir borçlar hukuku sözleşmesinden ileri bir nitelik verilmesi arzulanmıştır.

Sözleşme’nin diğer maddelerinde ise betimleme yeniden kullanılmamış, bunun yerine tanımanın sözleşme kapsamına alınan bölümü ve sulh anlaşmalarının icra edilebilirliğini içerecek şekilde “relief” ifadesi tercih edilmiştir ${ }^{39}$. Kanaatimizce relief ifadesinin Türkçe karşılığı olarak "hukuki çare" ifadesi kullanılabilir ${ }^{40}$. Bununla birlikte bu ifadenin Sözleşme ile amaçlanan hususları tam olarak karşılamadığı değerlendirilmektedir. Yukarıda açıklandığı üzere, yabancı mahkeme ve hakem kararlarının tanınması ve tenfizine göre mahiyeti farklı olsa da Singapur Sözleşmesi’nin sulh anlaşmalarının kesin delil olarak tanınması ve icra edilebilirliğini düzenlediği konusunda bir tereddüt bulunmamaktadır. Bu inceleme kapsamında "relief” kavramının karşılığı olarak sulh anlaşmasının kesin delil niteliğinin tanıması (okunma kolaylığının sağlanması açısından bu aşamadan itibaren kısaca tanıma denilecektir) ve icra edilebilirliği ifadeleri kullanılacaktır.

İki sözleşme arasındaki farklarla ilgili son olarak, New York Sözleşmesi’nin tanınması ve tenfizi talep edilen hakem kararlarının yabancı olmasını öngördügü, buna karşılık Singapur Sözleşmesi’nin tanınması ve icra edilebilirliği talep edilen sulh anlaşmalarının uluslararası

38 HMK 204 ve 205'inci maddeleri kapsamında ilamlar, sahteliği ispat olunmadıkça düzenleme niteliğindeki noter senetleri ile Mahkeme huzurunda ikrar olunan veya aksi ispat edilmedikçe mahkemece inkâr edenden sadır olduğu kabul edilen adi senetler kesin delil sayılırlar. Singapur Sözleşmesi yürürlüğe girmesi ile birlikte, Anayasa’nın 90'ıncı maddesi kapsamında kanun gücünü kazanacaktır. Bu bağlamda kanun gücü taşıyan Sözleşme ile sulh anlaşmalarına kesin delil niteliğinin verilmiş olacağını düşünmekteyiz. Söz konusu düşüncemiz kabul görmese dahi, iki taraf ve arabulucunun imzasını taşıyan sulh anlaşmalarının mahkemelerce inkâr edenden sadır olduğu kabul edilen adi senetler olarak kesin delil niteliklerinin kabul edilebileceğini değerlendirmekteyiz.

39 Relief ifadesi Özsunay tarafından Türkçeye “icra” şeklinde çevrilmiştir. Bkz. Özsunay, s. 35, 38 ve 40. Relief ifadesi bir İngilizce-Türkçe hukuk sözlügünde ise mağduriyetin izalesi, telafi, haksızlığın telafisi; herhangi bir külfetten muafiyet şeklinde çevrilmiştir. Bkz. Ovacık M., İngilizce-Türkçe Hukuk Sözlüğü, 3. Baskı, Banka ve Ticaret Enstitüsü, 2000, s. 272-273; Bir başka sözlük ise relief ifadesinin karşılığı olarak rahatlama, telafi, avuntu ifadesini kullanmıştır. Bkz. Yaşa Y, İngilizce-Türkçe/ Türkçe-İngilizce Hukuk Terimler Sözlüğü, Beta, 6. Bası, s. 144.

40 Nitekim, İngilizce hukuki terimler sözlüğü olan Black’s Law Dictionrary’da relief ifadesi şu şekilde açılklanmıştır: “The redress of benefit, esp. Equitable in nature (such as injunction or specific performance) that a party asks of a court. Cf REMEDY", Sözlüğün atıfta bulunduğu remedy kelimesi ise "The means of enforcing a right or preventing or redressing a wrong, legal or equitable relief-remedy vb Cf. RELIEF.” şeklinde açıklanmıştır. Bkz. Black's Law Dictionary, Garner B. A, Edt in Chief, Second Pocket Edition, 2001, s. 596 ve 698. 
nitelikte olmasını aradığı not edilmelidir. Diğer bir anlatımla, Singapur Sözleşmesi arabuluculuk sonucunda oluşan sulh anlaşmalarına bir milliyet atfetmemiş ve uygulama alanını tespit ederken milliyet esasından hareket etmemiştir ${ }^{41}$. Bu tercih bilinçlidir ve Singapur Sözleşmesi’nin kapsamının belirlenmesi bakımından “arabuluculuk yeri”nin bir öneminin olmadı̆̆ını ortaya koymaktadır ${ }^{42}$. Oysaki New York Sözleşmesi tahkim yeri ve tahkim yeri hukukuna önemli bazı sonuçlar bağlamıştır. Bu bağlamda örneğin, New York Sözleşmesi m. V(d) hükmü uyarınca tahkim sözleşmesinde kararlaştırılmamış ise tahkim heyetinin oluşumu ve tahkim usulü, tahkim yeri hukukuna tabi kılınmış ve bu hukuka uygun hareket edilmemesi halinde tanıma ve tenfiz talebinin reddedilebileceği öngörülmüştür. Singapur Sözleşmesi kapsamında ise "arabuluculuk yeri” hukukunun usul kurallarına (örneğin arabuluculuğun lisanslı bir arabulucu tarafından yürütülmesi, belli bir usulün takip edilmesi ve belli bir kuruma bağlı olarak yürütülmesi) uyulmamış olması, arabuluculuk süreci sonucunda oluşan anlaşmaya icra kabiliyeti verilmesini engellemeyecektir ${ }^{43}$. Bununla birlikte, bu durum tanıma ve icra edilebilirlik kararının ulusal hukuk kurallarından tamamen bağımsız olarak verileceği anlamına gelmemektedir. Arabuluculuk sonucunda varılan sulh anlaşmalarının tanınması ve icra edilebilirliğine ilişkin şartlar ve red sebepleri aşağıda ayrıntılı olarak ele alınacaktır.

\section{Singapur Sözleşmesi'nin Kapsamı}

Singapur Sözleşmesi'nin 1(1)'inci maddesi uyarınca; Sözleşme uluslararası nitelikteki ticari uyuşmazlıkları arabuluculuk yoluyla çözüme kavuşturan ve taraflarca yazılı olarak yapılan sulh anlaşmalarına uygulanacaktır. Sözleşme’nin 1(2) ve 1(3)'üncü maddeleri ise nitelikleri gereği uygulama alanı dışında kalan anlaşmaları belirtmiştir. Bu kapsamda, Sözleşme’nin uygulama alanı bulması için anlaşmanın i) arabuluculuk süreci sonucunda oluşmuş olması, ii) uluslararası nitelikte olması, iii) yazılı olması ve iv) ticari bir uyuşmazlığa ilişkin olması şeklinde dördü olumlu ve özel olarak kapsam dişında bırakılan anlaşmalardan olmama şeklinde biri olumsuz olmak üzere beş şartı birlikte yerine getirmesi gereklidir. Bu şartlar sırasıyla aşağıda ele alınacaktır.

\section{A. Anlaşmanın Arabuluculuk Süreci Sonucunda Oluşması}

Singapur Sözleşmesi’nin uygulama alanı bulması için her şeyden evvel sulh anlaşmasının arabuluculuk süreci sonucunda oluşması gereklidir. Sözleşme’nin müzakereleri sırasında arabuluculuk süreci olmaksızın taraflar arasında varılan anlaşmaların da Sözleşme kapsamına dahil edilmesi, en azından Deklarasyon yayınlama yoluyla taraf Devletlere böyle bir imkanın verilmesi tartışılmış ise de; nihai olarak ortaya çıkan metinde bu hususlara yer verilmemiş,

41 Erdoğan E., Milletlerarası Arabuluculuk Anlaşma Belgelerinin İcrasına İlişkin BM Sözleşmesinin (Singapur Sözleşmesi) Değerlendirilmesi, Arabuluculuğun Geliştirilmesi Uluslararası Sempozyumu, 6-7 Aralık 2018, Ankara, s. 192; Yarar G., Milletlerarası Özel Hukukta Arabuluculuk, On İki Levha Yayıncıllk, 2019, s. 158.

42 Claxton, s. 4-5; Chong/ Steffek, s. 456.

43 Claxton, s. 4-5; Erdoğan s. 192; Schnabel, s. 21. 
Sözleşme arabuluculuk süreci sonucunda ortaya çıkan sulh anlaşmalarına münhasır kılınmıştır ${ }^{44}$. Sözleşme arabuluculuğu 2'nci maddesinde şu şekilde tanımlamıştır: “Arabuluculuk", kullanılan ifadeden veya sürecin yapıldığı temelden bağımsız olarak, taraflara herhangi bir çözümü dayatma yetkisi olmayan üçüncü bir kişi veya kişilerin (arabulucu) yardımı ile tarafların aralarındaki uyuşmazlığı dostane olarak çözüme kavuşturmaya çalıştıkları süreci ifade eder. Söz konusu tanım UNCITRAL Model Kanunu'nun 1(3)'üncü maddesinde yer alan tanım esas alınarak yapılmıştır ${ }^{45}$. Model Kanun'un hazırlanış felsefesine uygun olarak Sözleşme arabuluculuk tanımını bilinçli olarak geniş tutmuş, bu bağlamda yalnızca "yapılandırılmış"46 bir süreç sonrasında taraflarca varılan anlaşmaları değil, arabulucunun yardımıyla resmi olmayan süreçler sonucunda ulaştıkları anlaşmaları da kapsam içerisine almıştır ${ }^{47}$. Keza varılan anlaşmanın Sözleşme kapsamında değerlendirilmesi için arabuluculuğun Sözleşmeye taraf bir Devletin iç hukuk mevzuatı ile öngörülen usule uygun olarak yürütülmesi şart olmadığı gibi, herhangi bir kurumsal yapı içerisinde gerçekleşmesine de gerek yoktur.

Arabuluculuk süreci sonucunda ortaya çıkan anlaşmanın dayandığı temel de Sözleşme kapsamının belirlenmesi açısından önem arz etmemektedir. Taraflar arasında varılan anlaşma; gönüllü arabuluculuk süreci sonucunda ortaya çıkabileceği gibi, tarafların zorunlu olarak arabuluculuk sürecine yönlendirildiği, ancak uzlaşının gönüllü gerçekleştiği bir süreç sonrasında da oluşabilir ${ }^{48}$. Bu bağlamda, ülkemiz uygulamasında olduğu gibi ticari uyuşmazlıklar için dava şartı olarak öngörülen arabuluculuk süreci sonucunda varılan anlaşmaların Sözleşme kapsamında değerlendirileceğini ifade etmek yerinde olacaktır. Öte yandan, arabulucuya başvurma zamanı da Sözleşme’nin uygulama alanının belirlenmesi açısından önem arz eden bir husus değildir. Taraflar aralarındaki uyuşmazlığı dava veya tahkim sürecine taşımadan önce arabuluculuğa başvurabileceği gibi, dava veya tahkim sürecinin devamı sırasında da arabulucuya yönelebilirler ${ }^{49}$. Önemli olan; taraflarca varılan anlaşmanın uyuşmazlığın mahkeme veya hakem kararı çözümü

44 Schnabel, s. 18-19; Yarar, s. 156.

45 Bu noktada 2002 yılında hazırlanan ve Türkiye tarafından da Arabuluculuk Kanunu hazırlanması aşamasında dikkate alınan Model Kanun'un arabuluculuk kavramı için “Conciliation” ifadesini kullandığ1, 2018 yılında Model Kanun'da yapılan değişiklikler sonrasında ise "Mediation” ifadesini tercih ettiğini belirtmekte yarar bulunmaktadır. Öte yandan, Model Kanun'un 2018 yılında kabul edilen halinde bu iki kavramın birbiri yerine kullanılabileceğinin ifade edildiğinin altı çizilmelidir (Model Kanun, 2'nci dipnot). Kanaatimizce de; arabuluculuk süreci tarafların üçüncü bir kişinin yardımı ile kendi çözümlerini ürettiği bir süreci ifade etmekte olup, süreci tanımlamak için kullanılan ifadenin bir önemi bulunmamaktadır. Bu bağlamda İngilizce olarak kullanılan "Conciliation" veya "Mediation" ifadelerinin Türkçeye "arabuluculuk" olarak çevrilmesi veya birbiri yerine kullanılmasında bir sakınca görmediğimizi vurgulamak isteriz.

46 Bu yönüyle Sözleşmede yer alan tanımlamanın HUAK’da yer alan tanımlamadan daha geniş tutulmuş olduğu belirtilmelidir. Her ne kadar HUAK'da “yapılandırılmış” ifadesine yer verilmemişse de; Kanun'un 2'nci maddesinde arabuluculuğu tanımlamak üzere kullanılan "sistematik teknikler uygulama" tarafların "birbirlerini anlamalarını ve bu suretle çözümlerini kendilerinin üretmelerini sağlama”, taraflar arasında "iletişim sürecinin kurulmasını gerçekleştirme” ifadeleri Kanun tarafından benimsenen yaklaşımın "yapılandırılmış" bir sürece işaret ettiğini göstermektedir. Bkz. Türkiye Cumhuriyeti Adalet Bakanlığı, Arabuluculuk Daire Başkanlığı, Temel Arabuluculuk Eğitimi Katılımcı Kitabı, s. 28.

47 Erdoğan s. 191; Schnabel, s. 15-16.

48 Schnabel, s. 17; Yarar, s. 156.

49 Schnabel, s. 16-17. 
öncesinde gerçekleşmesidir. Zira, mahkeme veya hakem kararlarının Sözleşme kapsamında girmediği açık olduğu gibi, bu süreçlerin bir parçası olarak onaylanan anlaşmaların da Sözleşme kapsamına girmediği Sözleşme’nin 1(3)'ncü maddesi ile kesin olarak ortaya konmuştur.

Öte yandan, varılan anlaşmanın arabuluculuk süreci sonucunda oluştuğunun kabulü için arabulucunun sürece ne kadar dahil olması gerektiği konusunda Sözleşmede bir açıklık yoktur ${ }^{50}$. $\mathrm{Bu}$ konuda; spektrumun bir ucunda arabulucunun sadece tarafları bir araya getirdiği geri kalan müzakere ve anlaşma sürecinin taraflarca gerçekleştirildiği durumlar yer alırken, diğer ucunda arabulucunun sürece aktif olarak katıldığı, hatta taraflarının çözüm üretemedikleri durumlarda çözüm önerisi getirdiği haller yer almaktadır. Kanaatimizce Sözleşme’nin arabuluculuğu teşvik ve taraf Devletlere mümkün olduğu ölçüde esneklik tanıma amaçları gözetildiğinde; spektrumun her iki ucunda yer alan anlaşmaları da kapsayacak şekilde konu en geniş şekilde ele alınmalıdır. Bu konudaki ölçütün, tarafların arabulucunun yardımı ile bir araya gelmesi ve herhangi bir dayatma olmaksızın bir çözüm üzerinde anlaşmaları olması gerektiğini düşünüyoruz ${ }^{51}$. Söz konusu çözüm arabulucunun minimum düzeyde katılım sağladığı bir süreç sonrasında şekillenebileceği gibi, arabulucunun sürece daha müdahil olduğu, hatta tarafların anlaşamamaları halinde arabulucu tarafından getirilen çözüm önerisini kabul ettikleri bir süreç sonrasında da oluşabilir. Tarafların arabulucu tarafından getirilen çözüm önerisini gönüllü olarak kabul etmeleri halinde, bu çözüm artık onların anlaşmaları olarak kabul edilmelidir. Kanaatimizce, Sözleşme tarafından öngörülen anlaşmanın arabuluculuk süreci sonucunda oluşmuş olması şartı; tarafların arabulucu olarak adlandırılan üçüncü bir kişinin yardımı ile gönüllü olarak uzlaştıkları her türlü anlaşmayı kapsamaktadır.

\section{B. Anlaşmanın Uluslararası Nitelikte Olması}

Sözleşme kapsamının belirlenmesi için göz önüne alınması gereken ikinci şart arabuluculuk süreci sonucunda taraflar arasında varılan anlaşmanın uluslararası nitelikte olması kriteridir. Anlaşmanın uluslararası nitelikte olması ise, temel olarak tarafların işyerlerinin farklı ülkelerde bulunması durumuna bağlanmıştır. Singapur Sözleşmesi ile benimsenen bu yaklaşımın Milletlerarası Mal Satımına İlişkin Sözleşmeler Hakkında Birleşmiş Milletler Antlaşması̉dan $(\mathrm{CISG})^{52}$ esinlenilerek oluşturulduğu görülmektedir ${ }^{53}$. Bu bağlamda, sulh anlaşmasının yapıldığ 1 anda tarafların işyerlerinin farklı devletlerde olup olmaması, anlaşmanın uluslararası nitelikte olup olmadığını belirlemektedir ${ }^{54}$. Kanaatimizce anlaşmanın uluslararası niteliğinin tespitinde

50 Schnabel, s. 17; Silvestri E., The Singapore Convention on Mediated Settlement Agreements: A New String to the Bow of International Mediation?, Revista Eletrônica de Direito Processual - REDP. Rio de Janeiro. Ano 13. Volume 20. Número 2, 2019, s. 192.

51 Erdoğan, s. 191; Yarar, s. 156.

52 CISG (United Nations Convention on Contracts for the International Sale of Goods) Türkiye tarafından da onaylanarak 1 Ağustos 2011 tarihi itibariyle yürürlüğe konulmuştur (RG: T. 07.04 2010, S. 27545).

53 CISG, m. 1; Erdoğan, s. 193; Schnabel, s. 21.

54 Çalışkan Y., Uluslararası Satım Hukukunda Kanunlar İhtilafı Meseleleri, Beta Yayınları, 2014, s. 129. 
işyeri esasından hareket edilmesi Sözleşme’nin uluslararası ticari arabuluculuğa ilişkin olması nedeniyledir.

Uluslararası ticari arabuluculuk açısından pek çok olay bu hal içerisine girmekle beraber, tarafların işyerlerinin aynı ülkede olduğu bazı durumlarda da sulh anlaşması uluslararası nitelikte olabilir. Bu bağlamda, Sözleşme anlaşmanın uluslararası olma niteliğini belirlerken ilave kriterler de benimsemiştir. Singapur Sözleşmesi’nin 1(b) maddesine göre; anlaşma kapsamındaki yükümlülüklerin önemli bir bölümünün tarafların işyerlerinin bulunduğu ülkeden farklıbir ülkede ifa edilecek olması veya anlaşma konusunun başka bir ülke ile daha sıkı ilişkili olması hallerinde anlaşmanın uluslararası nitelikte olduğu varsayılacaktır. Sözleşmenin 2(1)(a) maddesine göre ise, taraflardan birinin birden fazla iş yeri olması durumunda, taraflarca bilinen veya dikkate alınan koşullar değerlendirilerek anlaşma ile çözülen uyuşmazlıkla en yakın ilişkiye sahip olan işyeri esas alınacaktır. Sözleşmenin 2(1)(b) maddesi de bir tarafın iş yerinin bulunmaması halinde, ilgili tarafın mutad meskeninin bulunduğu yerin temel alınacağını öngörmektedir.

Bu konuyla ilgili son olarak, Singapur Sözleşmesi uygulama alanını belirlerken yabancılık unsurundan hareket etmemiş ise de, milletlerarası özel hukuk ve milletlerarası tahkim uygulamasında uluslararası ticari işlemler bakımından "yabancılık unsuru” kavramının geniş olarak ele alındığı vurgulanmalıdır ${ }^{55}$. Bu bağlamda doktrinde klasik anlamda yabancılık unsuru içermese dahi milletlerarası ticaret menfaatlerinin söz konusu olduğu durumlarda hukuki ilişkinin yabancı unsurlu olarak kabul edilmesi gerektiği konusunda bir anlayışın hakim olduğu vurgulanmalıdır ${ }^{56}$. Yine, Türk Milletlerarası Tahkim Kanunu 2'nci maddesinin birinci ve ikinci fikralarında "yabancılık unsuru"nun var olup olmadığı değerlendirmesinde Singapur Sözleşmesi’nde yer verilen kriterlerin temel alındığının altı çizilmelidir. Bu bağlamda, milletlerarası ticari ilişkiler bakımından "yabancılık” unsuru konusundaki anlayış ile Singapur Sözleşmesi’nde yer verilen "uluslararasılılık” anlayışı arasında belli ölçüde bir uyuşmanın olduğunu ifade edebiliriz. Bu uyuşmaya rağmen, Singapur sözleşmesinde yabancilık unsuruna yer verilmemesinin "arabuluculuk yeri” ve buna bağlanan sonuçlardan kaçınmak olduğu yukarıda açıklanmıştı ${ }^{57}$.

\section{Arabuluculuk Süreci Sonucunda Oluşan Anlaşmanın Yazılı Olması}

Arabuluculuk süreci sonucunda taraflar arasında varılan anlaşma yazılı olarak yapılmalıdır. Yazılılık şartı bir yandan anlaşmanın arabuluculuk süreci sonucunda oluştuğunu gösterecek, diğer yandan da varılan sulh anlaşmasının içeriğinin tespitini sağlayacaktır. Bu anlamda, yazılılık şartı

55 Özel S., Milletlerarası Ticari Tahkimde Kanunlar İhtilafı Meseleleri, Legal Yayıncılık, 2008, s. 21-26.

56 Aygün M., Yabancılık Unsurunun Mahiyeti ve Yargılamadaki Rolü, Dokuz Eylül Üniversitesi Hukuk Fakültesi Dergisi, 2014, s. 1031-1032; Çelikel / Erdem, s. 369-370; Doğan V., Milletlerarası Özel Hukuk, 5. Baskı, Savaş Yayınevi, 2019, s. 6; Şanlı C., Uluslararası Ticari Akitlerin Hazırlanması ve Uyuşmazlıkların Çözüm Yolları, 7. Bası, Beta Yayınları, 2019, s. 9-10; Tiryakioğlu B. Taşınır Mallara İlişkin Milletlerarası Unsurlu Satım Akitlerine Uygulanacak Hukuk, Ankara, Ankara Üniversitesi Hukuk Fakültesi Yayınları, 1996, s. 7. 
mahkeme ve taraflar açısından ispat işlevi görecektir. Yazılılık esasen tarafları süreç sonucunda varılan anlaşmanın içeriği hakkında düşünmeye sevk etme bakımından da yararlıdır. Singapur Sözleşmesi’nin öngördüğü yazılılık şartı resmi yazılı şekil olmayıp adi yazılı şekildir. Diğer bir anlatımla, arabuluculuk anlaşmasının geçerliliği herhangi bir makam önünde yapılmasına bağlı olmadığı gibi, herhangi bir makamın onayına da bağlı değildir. Bu noktada, Sözleşmenin çifte exequatur'dan özellikle kaçındığ 1 vurgulanmalıdır ${ }^{58}$.

Sözleşme ile aranan yazılılık koşulunun temel amacı; anlaşmanın içeriğinin kayıt altına alınması ve bu kayda daha sonra erişilmesidir. Bu bağlamda, Sözleşme’nin genel ruhuna uygun olarak "yazılılık” şartı da pratik ihtiyaçlar göz önüne alınarak düzenlenmiş ve arabuluculuk süreci sonucunda oluşan anlaşmanın içeriğini herhangi bir biçimde kayıt altına alan her türlü form ile yazılılık koşulu karşılanacaktır ${ }^{59}$. Bu açıdan, anlaşmanın kağıda dökülmesine gerek yoktur. Elektronik olarak tutulan ve daha sonra aynı şekilde ulaşılabilen kayıtlar da anlaşmanın içeriğini tespit edebilecektir. Bu kapsamda, modern uluslararası ticaret hayatının gereklerine uygun olarak, içeriğinde yer alan bilgilere daha sonra erişilebilir olması şartıyla elektronik iletişim araçları kullanılarak oluşturulan sulh anlaşmalarının Sözleşme kapsamında yazılı olarak kabul edileceği özel olarak vurgulanmıştır ${ }^{60}$. Örneğin taraflar ve arabulucunun tamamen farklı ülkelerde bulunduğu aralarındaki iletişimin video konferans gibi yollarla sağlandığı ve nihayetinde ortaya çıkan uzlaşının elektronik posta ile kayıt altına alındığı bir sulh anlaşması Sözleşme’nin uygulama alanına girecektir ${ }^{61}$. Öte yandan, anlaşmanın tek bir dokümanda yer almasına da ihtiyaç yoktur. $\mathrm{Bu}$ kapsamda örneğin, taraflar arasındaki anlaşmanın içeriğinin aralarındaki gidip gelen 45 e-postadan çıkarılması halinde de anlaşmanın var olduğu kabul edilecektir ${ }^{62}$.

\section{Arabuluculuk Süreci Sonucunda Oluşan Anlaşmanın Ticari Bir Uyuşmazlığa ilişkin Olması}

Sözleşme kapsamına giren bir anlaşmadan söz edilebilmesi için, anlaşmanın ortaya çımasına neden olan uyuşmazlığın ticari olması gereklidir. Hangi tür uyuşmazlıkların ticari olduğu Singapur Sözleşmesi’nde tanımlanmamıştır. Bununla birlikte, aynı konunun ele alındığı Model Kanun'da yer verilen tanımlama ve Sözleşme’nin genel amacı göz önüne alındığında bahse konu kavramın mümkün olduğunca geniş olarak yorumlanması gerektiği anlaşılmaktadır ${ }^{63}$. Bu bağlamda, Model Kanun'un 1 nolu dipnotunda “ticari” kavramının sözleşmesel bir ilişki olsun veya olmasın, ticari nitelikteki tüm ilişkilerden kaynaklanan sorunları kapsayacak şekilde geniş

58 Chong/Steffek, s. 462; Sussman, s. 51.

59 Chua, s. 195; Singapur Sözleşmesi m. 2 (2).

60 Singapur Sözleşmesi m. 2 (2); Öte yandan benzer bir anlayışın New York Sözleşmesi kapsamında da geçerli olduğu vurgulanmalıdır. Nitekim, New York Sözleşmesi’nde yazılılık bağlamında mektup ve telgraftan bahsedilmiş olmasına rağmen, günümüz uluslararası ticaret hayatının gerekleri ve teknolojik gelişmeler dikkate alınarak elektronik araçlar kullanılarak yapılan tahkim sözleşmelerinin de geçerli olacağı doktrin ve uygulamada kabul edilmektedir. Bu konu ile ilgili olarak Bkz. Akıncı, s. 117 ; Özdemir Kocasakal H., Elektronik Sözleşmeden Doğan Uyuşmazlıkların Çözümünde Uygulanacak Hukukun ve Yetkili Mahkemenin Tespiti, İstanbul, 2003, s. 222-225; Şanlı, s. 448.

61 Chong/Steffek, s. 467.

62 Schnabel, s. 28-29.

63 Claxton, s. 1. 
yorumlanması gerektiği açıklanmıştır. Ticari nitelikteki ilişkilere ise mal veya hizmet tedariki veya değişimi, dağıtım anlaşmaları, ticari temsil veya acentelik, faktöring, leasing, yapım işleri, danışmanlık, mühendislik, lisans, yatırım, finansman, bankacılık, sigorta, işletme veya imtiyaz anlaşmaları, ortak girişim ve diğer sanayi veya ticari işbirliği biçimleri ile mal veya yolcuların hava, deniz, demiryolu veya karayolu ile taşınmasına ilişkin işlemler örnek niteliğinde sayılmıştır. Tüm bunlara ilave olarak, yapım ve doğal kaynakların çıkarılmasına ilişkin olarak devlet ile yatırımcı arasında ortaya çıkan yatırım uyuşmazlıklarının da ticari uyuşmazlık olarak sayılması gerektiği öne sürülmüştür ${ }^{64}$. Bununla birlikte, aşağıda ele alınacağı üzere ticari olsun veya olmasın bazı tür anlaşmalar özel olarak Sözleşme kapsamı dışında tutulmuştur. Bu kapsamda Sözleşme’nin uygulama alanı tespit edilirken ilişkinin kapsam dışında tutulan bir konu olup olmadığı da dikkate alınmalıdır.

\section{E. Singapur Sözleşmesi Tarafından Özel Olarak Kapsam Dışında Tutulan Anlaşmalardan Olmama}

Bazı tür anlaşmalar özel olarak Singapur Sözleşmesi’nin kapsamı dişında tutulmuştur. Diğer bir anlatımla, Sözleşme tarafından özel olarak kapsam dışında bırakılan bu tür anlaşmaların, arabuluculuk süreci sonucunda oluşup oluşmadığına veya diğer koşulları sağlayıp sağlamadığına bakılmaksızın, tanınması ve icra edilebilirliği talep edilemeyecektir. Sözleşme kapsam dışında bıraktığı anlaşmaları iki grup altında toplamış ve sırasıyla 1(2) ve 1(3)'üncü maddelerinde düzenlemiştir.

İlk grupta yer alan anlaşmalar nitelikleri gereği Sözleşme’nin uygulama alanı dışında bırakılmıştır. Sözleşme’nin 1(2)'nci maddesine göre; Sözleşme taraflardan birinin tüketici sıfatıyla kişisel, ailevi ve ev ihtiyaçları için yapmış olduğu işlemlerden kaynaklanan uyuşmazlığı çözen anlaşmalara uygulanmayacağı gibi aile, miras veya iş hukuku ile ilgili uyuşmazlıkları çözen anlaşmalar bakımından da uygulama alanı bulmayacaktır. Bu tür uyuşmazlıklar ticari uyuşmazlıklardan farklı özellikler taşımaları nedeniyle kapsam dışında bırakılmıştır. Esasen aynı durum milletlerarası tahkim bakımından da geçerlidir. Bu kapsamda örneğin, tüketici uyuşmazlıklarında tüketicinin korunmasına ilişkin emredici hukuk kuralları doğrudan uygulama alanı bulabilmekte, bu kurallara aykırı anlaşmalar geçersiz olabilmektedir ${ }^{65}$. Bu tür anlaşmaların kapsam dışında bırakılmasının diğer bir nedeni de; Özel Hukuka İlişkin Lahey Konferansı gibi farklı uluslararası kurumların çalışmaları ile bir çakışma yaşanmasından kaçınma isteğidir ${ }^{66}$.

İkinci grupta yer alan anlaşmalar ise yargı veya hakem kararlarının bir parçası olarak oluşmaları nedeniyle Sözleşme kapsamı dışında bırakılmıştır. Bu bağlamda, Sözleşme’nin 1(3)'üncü maddesinin a fikrasına göre; uyuşmazlığı çözen anlaşmanın mahkeme tarafından onaylanması veya mahkeme süreci içerisinde oluşması ve ilgili ülke mahkemesinde yargı kararı

Schnabel, s. 22-23.

Özel, s. 19.

66 Chua, s. 197; Chong/Steffek, s. 460. 
olarak uygulanabilir olması halinde, anlaşma Sözleşme’nin uygulama alanı dışında kalacaktır. Sözleşme’nin 1(3)'üncü maddesinin (b) fikrasında ise, hakem kararı olarak kaydedilen ve uygulanabilir olan anlaşmaların kapsam dışında olduğu belirtilmiştir.

Söz konusu anlaşmaların ticari nitelikte bir uyuşmazlı̆̆ çözüp çözmemesinin önemi yoktur. Zira bu tür anlaşmaların kapsam dışında bırakılmasının temel nedeni anlaşmanın ilgili olduğu uyuşmazlık çözüm sisteminin niteliğinden kaynaklanmaktadır. Sözleşme’nin 1(3)'üncü maddesi ile esas olarak uyuşmazlık çözüm sistemleri arasındaki muhtemel çatışmanın önlenmesi amaçlanmıştır. Diğer bir anlatımla, temel uyuşmazlık çözüm yöntemi olan yargısal çözüm yöntemi ve yine onu tamamlayan tahkim yolu ile bir tür alternatif uyuşmazlık çözüm yolu olan arabuluculuk arasında bir çatışmanın yaşanmasını önlemek bakımından yargısal ve tahkim çözüm yollarına üstünlük tanınmıştır. Bu tercihin arka planında ayrıca, Singapur Sözleşmesi ile 2005 tarihli Mahkeme Seçimine Dair Lahey Sözleşmesi ve New York Sözleşmesi gibi konuyu düzenleyen diğer uluslararası metinler arasında olası çatışmaların yaşanmasının önlenmesi amacı da bulunmaktadır ${ }^{67}$.

Bununla birlikte önemle belirtmek gerekir ki; uyuşmazlıkları çözen anlaşmaların yukarıda yer verilen fikralar kapsamında değerlendirilmesi için anlaşmaların mahkeme veya hakem kararı olarak addedilmesi veya bu süreçlerin bir parçası olarak onaylanması gerekmektedir ${ }^{68}$. Diğer bir ifadeyle, hakim ve tahkim hakeminin basit yönlendirmesi sonucunda tarafların arabulucuya başvurması ve anlaşmanın arabuluculuk süreci sonucunda oluşması halinde bu tür anlaşmalar Sözleşme kapsamında değerlendirilecektir ${ }^{69}$. Aksine bir düşünce bu tür anlaşmaların tanınması ve icrasına engel olacak, bu durum ise Sözleşme’nin genel amacına aykırı düşecektir.

\section{Singapur Sözleşmesi'ne Göre Arabuluculuk Sonucunda Oluşan Anlaşmaların Tanınması ve İcra Edilebilirliği}

\section{A. Genel}

Singapur Sözleşmesi uluslararası ticari arabuluculuk sonucunda varılan sulh anlaşmalarının tanınması ve icra edilebilirliği konusunda önce genel ilkeleri koymuş, akabinde tanıma ve icra edilebilirlik talebinde bulunan tarafın yerine getirmesi gereken usuli şartları, son olarak da tanıma ve icra edilebilirlik talebinin reddi sebeplerini düzenlemiştir. Genel ilkeler Singapur Sözleşmesi’nin 3’üncü maddesinde iki fikra halinde düzenlenmiştir. Singapur Sözleşmesi kapsamında tanıma ve icra edilebilirlikten ne anlaşılması gerektiği yukarıda açıklanmıştır. Aşağıda ise usuli şartlar ile tanıma ve icra edilebilirlik talebinin reddi sebepleri üzerinde durulacaktır. Sulh anlaşmalarının Sözleşmeye taraf ülkelerde çoğunlukla icrasının talep edileceği ve Sözleşme’nin 4 ve 5’inci

67 Chua, s. 197; Zeller B./ Trakman L., Mediation and Arbitration: The Process of Enforcement, Uniform Law Review 1; UNSW Law Research Paper No. 19-43, s. 6.

68 Hioureas, s. 221.

69 Yarar, s. 156. 
maddelerinde kullanılan "relief” ifadesinin tanıma ve icra edilebilirlik kavramlarını kapsayacak şekilde kullanılmış olması göz önüne alınarak, aşağıda yer verilen açıklamalar sulh anlaşmasının icra edilebilirliği esas alınarak yapılacaktır. Bununla birlikte açıklamaların sulh anlaşmasının "kesin delil" niteliğinin tanınması için de geçerli olduğu vurgulanmalıdır.

\section{B. İcra Edilebilirlik Talebinde Bulunulması Için Yerine Getirilmesi Gereken Usuli Şartlar}

Singapur Sözleşmesi kapsamına giren sulh anlaşmasının icra edilebilirliğini talep eden tarafın sınırlı sayıda bazı usuli şartları yerine getirmesi gerekmektedir. Sözleşme’nin 4'üncü maddesi söz konusu gereklilikleri düzenlemiştir. Bu bağlamda, icra edilebilirlik talebinde bulunan taraf ilgili ülkenin yetkili makamına i) taraflarca imza altına alınan anlaşmayı, ii) anlaşmanın arabuluculuk süreci sonucunda oluştuğunu gösteren kanıtları, iii) sulh anlaşmasının ilgili ülkenin resmi dilinden başka bir dilde olması ve ilgili ülkenin talebi halinde anlaşmanın tercümesini ve iv) Sözleşme'de öngörülen şartların yerine getirilmiş olduğuna dair yetkili makam tarafından talep edilebilecek diğer belgeleri sunmak zorundadır.

\section{I) Taraflarca Imza Altına Alınan Anlaşma}

Singapur Sözleşmesi’ne dayanarak icra edilebilirlik talebinde bulunan taraf, taraflarca imza altına alınan anlaşmayı ilgili ülkenin yetkili makamlarına sunmalıdır. Söz konusu şartın temel amacı; icra edilebilirlik kararı verecek ilgili ülke yetkili makamlarına anlaşmanın içeriğini ve tarafların kimliğini tespit etme imkanını sağlamaktır. Taraflar arasında varılan anlaşmanın içeriği tarafların herhangi bir formda kayıt altına aldıkları dokümandan çıkarılacaktır. Bu bağlamda, sulh anlaşmalarının yazılı olması ve yazılılıktan ne anlaşılması gerektiği yukarıda açıklanmıştı ${ }^{70}$.

Tarafların kimliğinin saptanması ise anlaşmanın taraflarca imza edildiğinin gösterilmesi yoluyla sağlanacaktır ${ }^{71}$. Yazılılık koşulunda olduğu gibi, imza koşulu bağlamında da Sözleşme uluslararası ticaret sisteminin pratik gereksinimlerini dikkate almış ve amaca matuf bir düzenlemede bulunmuştur. Bu doğrultuda, taraflar vardıkları anlaşmayı ıslak imza ile kayıt altına alabilecekleri gibi elektronik imza seçeneğini de kullanabilirler. Keza, yetkilendirilmiş taraf vekillerinin anlaşmayı imzalamaları da imza koşulunu yerine getirecektir ${ }^{72}$. Ayrıca, Sözleşme’nin 4’üncü maddesinin ikinci fikrası uyarınca tarafların kimliği ile anlaşmaya ilişkin rızalarının taraflardan gelen elektronik postalar gibi elektronik iletişim araçlarından çıkarıldı ğı durumlarda da, anlaşmaların taraflarca imza edilmiş olacağı kabul edilecektir.

70 Bkz. s. 991-992.

71 Kuşkusuz sulh anlaşması taraflarından birisi veya her ikisinin tüzel kişi olması halinde, imzanın tüzel kişiyi temsile yetkili kişi tarafından atılması gerekecektir. Tüzel kişinin kimin tarafından temsil edileceği, yani kim tarafından hak ve borç altına sokulabileceği tüzel kişinin ehliyeti ile alakalıdır. Singapur Sözleşmesi’nde taraf ehliyetine uygulanacak bir hükmün olmaması karşısında, ehliyet konusunda icra edilebilirlik kararını verecek devletin kanunlar ihtilafı kurallarının esas alınması gerektiği kanaatindeyiz. MÖHUK m.9(4) uyarınca Türk hukukunda tüzel kişilerin hak ve fiil ehliyetleri statülerindeki idare merkezi hukukuna tabi kılınmıștır. 


\section{2) Taraflar Arasında Varılan Anlaşmanın Arabuluculuk Süreci Sonucunda Oluştuğunu Gösterir Kanıtlar}

Uyuşmazlık tarafları arasında varılan anlaşmanın arabuluculuk süreci sonunda oluşması, Singapur Sözleşmesi’nin kapsamının belirlenmesi açısından şarttır. İcra edilebilirlik talebinde bulunulduğunda ise söz konusu şartın yerine getirildiği kanıtlanmalıdır. Kanıtlama en basit şekli ile anlaşmanın taraflar yanında arabulucu tarafından da imzalandığının gösterilmesi yoluyla yerine getirilecektir. Tipkı taraf imzalarında olduğu gibi, arabulucu imzası konusunda da Sözleşme pratik gereksinimlerden hareket etmiştir. Bu doğrultuda, arabulucu taraflarca varılan anlaşmayı ıslak olarak imzalayacağı gibi elektronik imza seçeneğini de kullanabilir. Keza, Sözleşme’nin 4 (2)'nci maddesi uyarınca; elektronik posta gibi taraflar ve arabulucu arasında yapılan elektronik yazışmalardan imza fonksiyonunun yerine getirildiğinin anlaşılması halinde, anlaşmanın arabulucu tarafından da imza edildiği kabul edilecektir.

Öte yandan, farklı ülkelerde geçerli farklı sistemler nedeniyle arabulucunun taraflarca varılan anlaşmayı imzalaması bir koşul olmayabilir veya değişik saikler ile arabulucunun taraflar arasındaki anlaşma metnine imza koyması istenmeyebilir ${ }^{73}$. Bu bağlamda anlaşmanın arabuluculuk süreci sonucunda oluştuğu farklı kanıtlar gösterilerek ispat edilebilir. Sözleşme’nin 4 (1)b hükmü uyarınca, ilgili taraf arabulucunun anlaşma metninden ayrı olarak imzaladığı bir dokümanı ibraz ederek de anlaşmanın arabuluculuk sonucunda oluştuğunu gösterebilir. Yine aynı hüküm arabuluculuk sürecini yöneten kurumun tasdikinin veya yetkili makam tarafından kabul edilebilecek diğer türlü kanıtların da anlaşmanın arabuluculuk süreci sonucunda oluştuğunu gösterebileceğini kabul etmiştir.

\section{3) Taraflarca Varılan Anlaşmanın Tercümesi}

Singapur Sözleşmesi’nin 4 (3)'üncü maddesi uyarınca, arabuluculuk süreci sonucunda varılan anlaşmanın icrasının talep edildiği ülkenin resmi dilinden farklı bir dilde olması halinde, yetkili makam anlaşmanın tercümesini talep edebilecektir. Söz konusu koşul mutlak olmayıp, ancak yetkili makamin talep etmesi halinde yerine getirilmesi gereken bir gereksinimdir. Diğer bir anlatımla, bu koşul icra edilebilirlik talebinde bulanan tarafın yetkili makama başvururken yerine getirmesi gereken bir ön-koşul olmayıp, süreç içerisinde ve talep halinde karşılanabilecek bir lüzumdur. Tercümenin nasıl olacağı, örneğin noter veya konsolosluk onayının gerekip gerekmediği konusunda Sözleşmede bir açıklık yoktur. Bu konuda talebin yapıldı̆̆ı ülkenin uygulaması esas alınacaktır. Ülkemiz uygulaması bakımından yabancı hakem kararlarının tanınması ve tenfizinde geçerli olan usulün arabuluculuk süreci sonucunda oluşan anlaşmalar bakımından aranması ve uygulamanın bu yönde gelişmesi makul olacaktır. Bu bağlamda, HMK 223 ve 224'üncü maddeleri kapsamında anlaşmaların Türkiye içerisinde noter onaylı 
tercümelerinin, yurt dışında ise konsolosluk onaylı tercümelerinin talep halinde mahkemeye sunulmasi gerekecektir ${ }^{74}$.

\section{4) Yetkili Makam Tarafından Talep Edilecek Diğer Belgeler}

Singapur Sözleşmesi’nin 4(4)'üncü maddesi uyarınca, icra edilebilirlik kararı verecek ülkenin yetkili makamları Sözleşmede öngörülen şartların yerine getirilmiş olduğuna dair gerekli herhangi bir belgeyi talep edebilecektir. Söz konusu hükmün temel amacı Singapur Sözleşmesi’nde öngörülen şartların var olup olmadığının teyididir. Bunun ötesinde, Sözleşme’nin genel amacı ve ruhu olan formalitelerin en aza indirilmesi hedefinin dolanılması için bu hüküm kullanılamayacaktır. Bu bağlamda örneğin arabuluculuk süreci sonucunda varılan anlaşma ve arabulucunun imzasının noter tarafindan onaylanmasını öngören bir belgenin aranması Sözleşme ile bağdaşmayacaktır ${ }^{75}$. Keza sulh anlaşmalarının tanınması ve icrası için apostille şerhi de aranmayacaktır. Yukarıda açıklandığı üzere, New York Sözleşmesi’nden farklı olarak Singapur Sözleşmesi sulh anlaşmalarına bir milliyet atfetmemiş, ayrıca arabuluculuk yerine bir sonuç bağlamamıştır. Bu bağlamda, milliyeti olmayan bir belgenin gerçekliğinin yabancı ülke makamlarından tasdiki (apostille) şartı da aranmayacaktır.

\section{C. İcra Edilebilirlik Talebinin Reddi Sebepleri}

New York Sözleşmesi’ne benzer şekilde Singapur Sözleşmesi arabuluculuk süreci sonucunda varılan anlaşmanın icra edilebilirliği talebinin, sınırlı olarak sayılan sebepler ile reddedilebileceğini öngörmüştür ${ }^{76}$. Söz konusu sebeplerin büyük çoğunluğu New York Sözleşmesi’nin V’inci maddesi esas alınarak düzenlenmiş, ancak arabuluculuk sürecine uygun uyarlamalar yapılmıştır ${ }^{77}$. Yine New York Sözleşmesi’nde olduğu gibi red sebeplerinin büyük kısmı icra edilebilirlik talebine itiraz eden tarafça ileri sürülmeli ve ispat edilmelidir. Bu kapsamda, kamu düzenine aykırılık ve uyuşmazlık konusunun arabuluculuk yöntemi ile çözülmeye elverişsiz olması dışındaki red sebeplerine dayanan taraf, red sebebini ileri sürmek ve bunu ispat etmekle yükümlüdür. Aşağıda Sözleşme’nin 5'inci maddesinde yer verilen red sebepleri sırasıyla ele alınacaktır.

\section{I) Tarafların Ehliyetsizliği}

Arabuluculuk süreci sonucunda varılan anlaşmayı imzalayan tarafın ehliyetli olması gereklidir. Ehliyet konusu genel olarak hak ve fiil ehliyeti şeklinde iki kısımda ele alınmaktadır ${ }^{78}$. Bununla birlikte, ilgili ülkeler ehliyetin kazanılması veya kaybını farklı şartlara bağlayabilmektedir.

\footnotetext{
74 Şanlı, s. 202-203.

75 Schnabel, s. 34.

76 Vasinova, s. 9.

77 Chua, s. 201.

78 Akınc1, s. 371.
} 
Tarafların ehliyetli veya ehliyetsiz olduklarının hangi hukuka göre tayin edileceği konusunda Singapur Sözleşmesỉnde bir açıklık yoktur. Oysa ehliyetsizlik konusunu aynı ifade (incapacity) ile ele alan New York Sözleşmesi taraf ehliyetlerinin "haklarında tatbiki gereken kanununa" göre tespit edileceğini hükme bağlamıştır ${ }^{79}$. Taraflara tatbiki gereken kanun tenfiz devletinin kanunlar ihtilafı kurallarına göre belirlenecektir ${ }^{80}$. Singapur Sözleşmesi kapsamında da ehliyet konusunda icra edilebilirlik kararını verecek devletin kanunlar ihtilafı kurallarının esas alınması gerektiği kanaatindeyiz. Türk hukuku bakımından ehliyete uygulanacak hukuk 5718 sayılı MÖHUK’un 9'uncu maddesi kapsamında tespit edilecektir. Bu bağlamda, kural olarak özel kişiler için ehliyet ilgilinin milli hukukuna göre belirlenecek iken, tüzel kişiler bakımından "idare merkezi” hukuku esas alınacaktır ${ }^{81}$.

\section{2) Arabuluculuk Süreci Sonucunda Varılan Anlaşmanın Hükümsüzlüğü, Etkisizliği, Uygulama Kapasitesinden Yoksun Olması, Bağlayıcı veya Nihai Olmaması veyahut Sonradan Değiştirilmesi}

Singapur Sözleşmesi’nin 5 (1)(b) hükmü arabuluculuk süreci sonucunda varılan anlaşmanın belli nitelikleri haiz olmaması durumunu red sebebi olarak düzenlemiştir. Bu haller üç alt başlıkta ele alınmıştır. Bu bağlamda, ilk olarak anlaşmanın hükümsüzlügü̈ (null and void), etkisizliği (inoperative) veya uygulama kapasitesinden yoksun olması (incapable of being performed) durumlarında, icra edilebilirlik talebi reddedilebilecektir. Söz konusu red sebebi New York Sözleşmesi’nin II.3 ve V.1(a) maddelerinden hareketle oluşturulmuştur. Bu bağlamda, hükümsüzlük, etkisizlik ve uygulama kapasitesinden yoksun olma durumlarının tespiti için New York Sözleşmesi’nin anılan hükümleri ve buna ilişkin yapilan yorumlardan yararlanılabilinir. $\mathrm{Bu}$ kapsamda örneğin, anlaşmanın hata, hile ve tehdit gibi taraf iradesini sakatlayan bir durum neticesinde oluşması halinde anlaşmanın geçersiz olduğu öne sürülebilecektir ${ }^{82}$. Bununla birlikte, Sözleşmede yer verilen hükümsüzlük, etkisizlik veya uygulama kapasitesinden yoksun olma durumları, icra edilebilirlik talebinin yapıldığı devletin arabuluculuğun gerçekleștirilmesi konusunda koymuş olduğu şekli şartlara uyulmaması hallerini kapsamamaktadır. Bu kapsamda örneğin, arabulucunun bir sicile kayıtlı olmaması veya süreçte belli bir usulün takip edilmemesi ve sürecin belli bir kuruma bağlı olarak yürütülmemesi gibi haller arabuluculuk süreci sonucunda oluşan anlaşmanın icra edilebilirliğini engellemeyecektir ${ }^{83}$.

Öte yandan, Sözleşme ehliyetin aksine anlaşmanın hangi hukuka göre geçersiz, hükümsüz veya uygulama kapasitesinden yoksun olduğunu düzenlemiştir. Sözleşme’ye göre söz konusu durumların varlığı, tarafların arabuluculuk süreci sonucunda varılan anlaşmayı tabi kıldıkları hukuk tarafından tespit edilecektir. Söz konusu tabi kılma hiç şüphesiz tarafların aralarında

79 New York Sözleşmesi, m. V(1)(a).

80 Özel, s. 68; Şanlı/ Esen / Ataman Figanmeşe, s. 684.

81 Ehliyet konusunda daha ayrıntılı bilgi için Bkz. Çelikel/Erdem, s. 202-212; ; Doğan, s. 282-300; Nomer E. Devletler Hususi Hukuku, 22. Bası, Beta Yayınları, 2017, s. 216-234; Şanlı/ Esen/Ataman Figanmeşe, s. 112-123.

82 Akıncı, s. 363; Şanlı/ Esen/Ataman Figanmeșe, s. 684.

83 Schnabel, s. 21. 
yaptıkları anlaşmaya koyacakları bir kayıt ile mümkün olabilecektir. Bu bağlamda, taraflar bu durumlara ilişkin hukuk seçiminde bulunabileceklerdir. Hukuk seçiminin yapılmadığı hallerde ise icra edilebilirliğin talep edildiği ülkenin yetkili makamı, kanunlar ihtilafı kurallarının işaret ettiği hukuka göre anlaşmanın geçersiz, hükümsüz veya uygulama kapasitesinden yoksun olduğu tespit edilecektir ${ }^{84}$.

Singapur Sözleşmesi 5 (1)(b) hükmü kapsamında ikinci olarak, arabuluculuk süreci sonucunda varılan anlaşmanın bağlayıcı veya nihai olmaması hali red sebebi olarak düzenlenmiştir. Sözleşmede kullanılan anlaşmanın kendi hükümleri uyarınca (according to its terms) ifadesi, anlaşmanın bağlayıcı veya nihai olmadığı halinin yalnızca anlaşma hükümlerine göre tespit edileceğini göstermektedir ${ }^{85}$. Diğer bir anlatımla, taraflar arasında varılan anlaşma dışında başka bir kaynağa, örneğin icra edilebilirliğin talep edildiği ülke hukukuna dayanılarak anlaşmanın bağlayıcı veya nihai olmadığı ileri sürülemeyecektir ${ }^{86}$. Tarafların arabuluculuk süreci sonucunda vardıkları anlaşmayı imza etmeleri karine olarak anlaşmanın taraflar açısından bağlayıcı ve nihai olduğunu gösterir. Bu durumun aksi ancak tarafların karşıt yöndeki iradelerini anlaşma metnine açık veya zımni olarak yansıtmalarına bağlıdır ${ }^{87}$. Bu kapsamda örneğin sulh anlaşması tarafları, bir tarafın uğradığı tazmin edilmesi konusunda anlaşmakla birlikte, zararın belli bir mercii veya kişi tarafından hesaplanmasını öngörebilirler. Bu halde seçilen mercii veya kişinin zararı hesaplamasından önce, sulh anlaşması için icra edilebilirlik talebinde bulunulması halinde diğer taraf anlaşmanın nihai olmadığını ileri sürerek icra edilebilirlik talebinde itiraz edebilir.

Singapur Sözleşmesi 5 (1)(b) hükmü son olarak arabuluculuk süreci sonucunda varılan anlaşmanın daha sonra değiştirilmiş olması durumunu red sebebi olarak saymıştır. Bu halde ancak değişikliğe uğramış sonraki anlaşma icra edilebilecek, ilk anlaşmanın icrasının talep edilmesi halinde ise bu talep reddedilecektir. ${ }^{88}$ Diğer bir deyişle, Sözleşme taraf iradelerinin birincil derecede rol oynadığı arabuluculuk süreci sonucunda varılan anlaşmanın taraf iradelerini eksiksiz yansıtmasını aramakta olup, bu nitelikten yoksun anlaşmanın icrasının mümkün olmadığını açık bir şekilde ortaya koymuştur.

84 Schnabel, s. 45; Türk hukuku bakımından MÖHUK'da arabuluculuk süreci sonucunda varılan sulh anlaşmalarına uygulanacak hukuk konusunda özel bir hüküm bulunmamaktadır. Bununla birlikte, sulh anlaşmasının akdi niteliği göz önüne alınarak, uygulanacak hukukun genel hüküm niteliğindeki MÖHUK m.24’ten hareketle tayin edilmesi mümkündür. Bu kapsamda ilk olarak, taraflarının sulh anlaşmasına uygulanacak hukuku sözleşme özgürlüğü ilkesi gereğince serbestçe seçebileceği kabul edilmelidir. Anlaşmanın akdi niteliği gereği, tarafların zımni hukuk seçiminde de bulunabilecekleri kabul edilmelidir. Tarafların açı veya zımni olarak seçmemeleri halinde, ise sulh anlaşmasına uygulanacak hukuk objektif bağlama kuralları ile belirlenecektir. MÖHUK m.24/4'te ifadesini bulan objektif bağlama kuralı; sözleşmeye uygulanacak hukukun seçilmediği hallerde, sözleşmenin en sıkı ilişkili yer hukukuna tabi olacağını öngörmektedir. Bu hukuk, karakteristik edim borçlusunun, sözleşmenin kuruluşu sırasındaki mutad meskeni hukuku, ticarî veya meslekî faaliyetler gereği kurulan sözleşmelerde karakteristik edim borçlusunun işyeri, bulunmadığı takdirde yerleşim yeri hukukudur. Ancak hâlin bütün şartlarına göre sözleşmenin, karakteristik edim borçlusunun mutad meskeni, işyeri veya yerleşim yeri hukukundan başka bir hukukla "daha sıkı ilişki" içinde olması halinde, bu hukuk uygulanacaktır.

85 Erdoğan, s. 199.

86 Schnabel, s. 46.

87 Chong/Steffek, s. 472.

88 Chong/Steffek, s. 472. 


\section{3) Anlaşmada Yer Verilen Yükümlülüklerin ífa Edilmiş Olması, Açık veya Algılanabilir Olmaması}

Singapur Sözleşmesi 5 (1)(c) hükmü kapsamında iki ayrı red sebebi düzenlenmiştir. Bu sebeplerden ilki arabuluculuk süreci sonucunda varılan anlaşmada yer verilen yükümlülüklerin ifa edilmiş olması halidir. Anlaşmada yer verilen yükümlülüklerin ifa edilmiş olmasına rağmen, bir tarafın yeniden ifa için icra edilebilirlik talebinde bulunması halinde, söz konusu talep reddedilecektir. Bu kapsamda örneğin, tahkim uygulamasında sıklıkla karşılaşıldığ sözleşmesinden kaynaklanan zarar ve ziyanın sigortadan tahsil edilmesine rağmen tazminatı konu alan sulh anlaşmasının yeniden ifası için icra edilebilirlik talebinde bulunulması halinde bu talep reddebilecektir ${ }^{89}$. Esasen açık olması nedeniyle Sözleşme kapsamında söz konusu halin red sebebi olarak düzenlenmesine gerek yoktur. Bununla birlikte, müzakerelere katılan bazı delegelerin talebi üzerine bu hükmün Sözleşmeye derç edildiği ifade edilmiştir ${ }^{90}$.

5 (1)(c) hükmü kapsamında düzenlenen diğer red sebebi ise icra edilebilirliği talep edilen yükümlülüğün açık veya algılanabilir olmaması halidir. Kanaatimizce bu halin bir red sebebi olarak düzenlenmesi, red sebeplerinin kapsamını potansiyel olarak genişletebilecek niteliktedir. Sözleşme’nin amacı göz önüne alındığında bu red sebebinin kapsamının dar yorumlanması ve anlaşma hükümlerinden bir yükümlülük çıkarımında bulunulmaması haline münhasır kılınmasının uygun olacağını değerlendirmekteyiz. Diğer bir anlatımla, yetkili makam anlaşmanın bir yükümlülük içerdiğini ve yükümlülüğün çerçevesini çizebildiği durumlarda 5 (1) (c)(i) hükmüne dayanarak icra edilebilirlik talebini reddetmemelidir ${ }^{91}$.

\section{4) İcra Edilebilirlik Kararı Verilmesinin Anlaşma Hükümlerine Aykırı Olması}

Arabuluculuk süreci ve süreç sonucunda varılan anlaşmanın en temel özelliği taraf iradelerini serbestçe yansıtmasıdır. Taraflar anlaşmanın içeriğini ve nasıl yerine getirileceğini şerbetçe kararlaştırabilirler. Bu bağlamda örneğin, anlaşmada yer alan bir yükümlülüğü belli bir miktar paranın ödenmesine, bir şartın yerine getirilmesine veya bir olayın vuku bulmasına bağlayabilirler. Keza anlaşmanın yalnızca belli bir ülkede icra edilmesi konusunda da anlaşabilirler. Hatta taraflar Singapur Sözleşmesi hükümlerinin kendi anlaşmaları bakımından uygulanmayacağını da kararlaştırabilirler (opt-out $)^{92}$. Bu hallerde, taraf iradelerinin aksine (kararlaştırılan şart yerine getirilmeden, öngörülen olay vuku bulmadan, anlaşma ile kararlaştırılan ülkeden başka bir ülke icra edilebilirlik talebinde bulunma gibi) bir tarafın icra edilebilirlik talebinde bulunması halinde, Sözleşme’nin 5 (1)(d) hükmü kapsamında bu talep anlaşmaya aykırı olması nedeniyle reddedilecektir ${ }^{93}$.

89 Şanl1/Esen/Ataman Figanmeșe, s. 681.

90 Schnabel, s. 47.

91 Schnabel, s. 48.

92 Erdoğan, s. 200.

93 Chong/Steffek, s. 473 


\section{5) Arabulucunun Arabulucu veya Arabuluculuk Süreci Için Öngörülen Standartlara Aykırı Davranışı}

Singapur Sözleşmesi’nin 5 (1)(e) hükmü; arabulucunun arabulucu veya arabuluculuk süreci için öngörülen standartlara ciddi ölçüde aykırı davranması ve bu davranış olmasaydı aleyhine icra edilebilirlik talebinde bulunulan tarafın anlaşmaya varmayacak olması durumunu bir red sebebi olarak düzenlemiştir. Bu hükmün uygulanması için birkaç şartın birlikte bulunması gerekmektedir. Her şeyden evvel arabulucu veya arabuluculuk süreci için öngörülmüş bir standardın varlığı gereklidir. Söz konusu standart arabulucunun yetkili kılındığı hukuk tarafından öngörülmüş bir standart olabileceği gibi tarafların arabulucu ile yapmış oldukları arabuluculuk sözleşmesinde de düzenlenmiş olabilir. Keza arabulucunun tabi olduğu kurum tarafından bir takım ilke ve standartlara uyulması zorunlu kılınmış olabilir. Öte yandan standart taraflar arabulucuya başvurmadan önce geçerli olmalıdır. Diğer bir anlatımla, icra edilebilirlik kararı verecek makam farazi, başka bir hukuk düzeni veya belli bir kurum tarafından sonradan öngörülen standarda dayanarak talebi reddetmeyecektir ${ }^{94}$. Kısaca uyulması gereken standart arabulucu ve arabuluculuk süreci için fiilen geçerli olan bir standart olmalıdır.

Bu hükmün uygulama alanı bulması için ikinci olarak standarda aykırı davranmanın ciddi (esaslı) olması gereklidir. Bu bağlamda, arabulucu ve arabuluculuk süreci için öngörülmüş standart ve ilkelerden basit sapmalar yeterli olmayacaktır. Son olarak standarda aykırı davranış ile ilgili tarafın anlaşmaya varma iradesi arasında nedensellik bağı bulunmalıdır ${ }^{95}$. Diğer bir ifadeyle, arabulucunun standarttan sapması nedeniyle ilgili taraf anlaşmaya rıza göstermelidir ${ }^{96}$.

\section{6) Arabulucunun Tarafsızlığını ve Bağımsızlığını Zedeleyen Durumları Taraflara Bildirmemesi}

Arabulucunun davranışı ile alakalı ikinci red sebebine Sözleşme’nin 5 (1)(f) maddesinde yer verilmiştir. Söz konusu madde arabulucunun tarafsızlığı ve bağımsızlığı konusunda haklı şüphe uyandıracak bir halin varlığının arabulucu tarafından taraflara bildirilmemesi, bu bildirmemenin bir tarafın iradesi üzerinde ciddi bir etkisinin olması ve bildirim olsaydı ilgili tarafın arabuluculuk süreci sonucunda varılan anlaşmaya rıza göstermeyecek olması halini red sebebi olarak düzenlemektedir. 5(1)(e) hükmünde olduğu gibi, 5 (1)(f) hükmünün uygulanması da bir dizi şartın gerçekleşmesine bağlıdır. Bu bağlamda hüküm ilk olarak arabulucunun bağımsızlık ve tarafsızlı̆̆ından şüphe duyulmasını haklı gösteren bir durumun varlığını aramaktadır. Arabulucunun bir tarafla iş ilişkisinin olması, bir tarafın vekilliğini yapması gibi durumlar bu hallere örnek gösterilebilir. İkinci olarak, arabulucunun tarafsızlığı ve bağımsızlığını gölgeye düşüren durum taraflara bildirilmemiş olmalıdır. Taraflar arabulucunun bağımsız ve tarafsız olmadığını biliyor veya arabuluculuk sürecini çevreleyen şartlardan tarafların bu hali objektif olarak bildikleri sonucuna varılıyor ise artık bu hal red sebebi olarak kabul edilmeyecektir. Üçüncü

94 Schnabel, s. 51.

95 Chong/Steffek, s. 473.

96 Erdoğan, s. 200. 
olarak, arabulucunun bağımsız ve tarafsız olmama hali bir tarafın anlaşmaya varma iradesini ciddi olarak etkilemelidir. Öyle ki; ilgili taraf bu durumu bilmiş olsa idi, arabuluculuk süreci sonucunda varılan anlaşmaya rıza göstermeyecek olmalıdır. Diğer bir anlatımla, bildirilmeyen hal alelade bir durum olmamalı, bildirmeyen hal ile ilgili tarafın sulh anlaşmasını yapma yönündeki iradesi arasında nedensel bir bağın bulunması gereklidir ${ }^{97}$.

Sözleşme’nin 5 (1)(f) hükmünün uygulanmasının bir dizi şarta bağlanması arabuluculuk sürecinin niteliği ile açıklanabilecek bir durumdur ${ }^{98}$. Nitekim, arabuluculuk tahkimden farklı olarak taraf iradesinin sonuca daha etkin olarak yansıdığı gönüllü bir süreci ifade eder. Bu anlamda, arabulucunun oluşan sonuca etkisi tahkim sürecine kıyasla sınırlıdır ve varılan anlaşma esas itibariyle tarafların anlaşmasıdır. Üstelik taraflar süreci her zaman sonlandırma imkanına sahiptir. Bu manada, taraflar bağımsız ve tarafsız olmayan birinin de aralarındaki uyuşmazlık için arabuluculuk yapmasını isteyebilirler. Bununla birlikte, arabulucunun bağımsız ve tarafsız olmaması, bunun bir taraftan saklanması ve bu durumun ortaya çıkan netice üzerinde etkili olması halinde, taraf iradesinin anlaşmaya tam olarak yansımadığı kabul edilmekte ve Sözleşme bu hali icra edilebilirlik talebinin reddi sebebi olarak kabul etmektedir ${ }^{99}$.

\section{7) İcra Edilebilirlik Kararının Kamu Düzenine Aykırı Olması}

İcra edilebilirlik kararının verilmesi, talebin yapıldığı ülkenin kamu düzenine aykırı olması halinde, talep yetkili makam tarafından re'sen reddedilebilecektir. Kamu düzeninin tam ve net bir tanımı yoktur. Soyut nitelikli olan bu kavramın içeriği zamana ve mekana göre değişiklik gösterir ${ }^{100}$. Bununla birlikte, kavramın en genel ifade ile bir ülkede mevcut hukuki, sosyal, siyasal ve ahlaki temel kurum ve kurallar bütününü içerdiği söylenebilir ${ }^{101}$. Singapur Sözleşmesi'nde hangi hususların kamu düzeninden olduğu konusunda bir açıklama yoktur. Bununla birlikte, New York Sözleşmesi’nde özdeş bir hüküm bulunmakta olup, bir konunun kamu düzeninden olup olmadığ hususunda söz konusu Sözleşme bağlamında gelişen uygulama ve içtihattan yararlanılabilinir. Bu kapsamda örneğin icra edilebilirlik kararının, talebinin yapıldığı devletin temel hukuki ve ahlaki kurallarına aykırılık oluşturması (kumar veya rüşvet alacağı veya ihracat ve ithalat yasakları gibi) ve arabulucunun bağımsızlı̆̆ını zedeleyen durumların varlığı hallerinde kamu düzenine aykırılık söz konusu olabilecektir ${ }^{102}$.

97 Schnabel, s. 53.

98 Abramson, s. 374.

99 Abramson, s. 375.

100 Akıncı, s. 404; Çalışkan, s. 90; Dayınlarlı K. Hakem Kararlarına Etkisi Bakımından Millî-Milletlerarası Kamu Düzeni, s. 1 http://www.dayinlarli.gen.tr/wp-content/uploads/2018/03/intes2003.pdf; son erişim tarihi 30 Kasım 2019; Topaloğlu M., Tahkimde Kamu Düzenin Etkisi, Internatıonal Conference on Eurasian Economies, 2013, s. 890891.

101 Dayınlarlı, s. 1. Nomer, s. 569-570; Şanlı/ Esen/ Ataman Figanmeşe, s. 702; Tanrıver, S., Yabancı Hakem Kararlarının Türkiye’de Tenfizi Bağlamında Kamu Düzeninin Etkisi, Milletlerarası Hukuk ve Milletlerarası Özel Hukuk Bülteni Cilt 17, 2011, s. 476. (Kamu Düzeni); Topaloğlu, s. 890-891.

102 Şanlı/ Esen / Ataman-Figanmeşe, s. 703-705; Kamu düzenine aykırılık oluşturabilecek diğer örnek durumlar için Bkz. Tanrıver (Kamu Düzeni), s. 480-491. 
Öte yandan, Singapur Sözleşmesi’nde yer verilen kamu düzeni kavramının New York Sözleşmesi uygulamasında olduğu gibi istisnai ve oldukça dar yorumlanması gereklidir ${ }^{103}$. Hatta yukarıda açıklandığı üzere, arabulucunun bağımsızlığı konusu Singapur Sözleşmesi kapsamında New York Sözleşmesi’nin hakemler için aradığı bağımsızlık koşuluna göre daha dar yorumlanmalıdır ${ }^{104}$. Diğer bir anlatımla, kamu düzenine aykırılık iddiası Sözleşme’de öngörülen diğer hükümlerin dolanılması amacıyla kullanılmamalıdır. Bu anlamda kamu düzeni kavramı yorumlanırken milletlerarası özel hukuk ilkeleri ışığında iç hukukta düzen menfaatinin sağlanması yanında Sözleşme’nin amaçları ve işlem güvenliği menfaatinin göz önüne alınması gerekir ${ }^{105}$. Bu bağlamda örneğin, Sözleşme uyuşmazlıkların arabuluculuk yoluyla çözümü için lisanslı bir arabulucuyu özellikle öngörmeği halde, yetkili makam kendi ülke uygulaması bakımından bu durumun kamu düzenini ihlal ettiği sonucuna varamayacaktır ${ }^{106}$. Singapur Sözleşmesi’nin uygulama alanının ticari uyuşmazlıklara münhasır olması nedeniyle, Sözleşme kapsamında red sebebi olarak kamu düzeni gerekçesinin kullanılmasını iyice daraltmaktadır. Bu kapsamda, kamu düzeninden sayılan hallerin çoğunlukla ulusal güvenlik ile alakalı hususlar ile ilgili olmasını düşünmek yerinde olacaktır ${ }^{107}$.

\section{8) Uyuşmazlık Konusunun Arabuluculuk Yöntemi ile Çözülmeye Elverişli Olmaması}

Arabuluculuk süreci sonucunda varılan anlaşmanın ait olduğu uyuşmazlık konusu icra edilebilirlik kararının talep edildiği ülkede arabuluculuk yöntemi ile çözülmeye elverişli değil ise, yetkili makam Sözleşme’nin 5 (2)(b) hükmü uyarınca bu talebi re’sen reddebilir. İcra edilebilirlik kararı talep edilen ülke bazı konuları arabuluculuk süreci ile çözümlenebilecek konulardan görmeyip, bu konulara dair uyuşmazlıkların yargı yoluyla çözülmesini öngörebilir. Hangi konuların arabuluculuğa elverişli olduğu konusunda devletlerin maddi hukuklarında yeknesak bir uygulama yoktur ${ }^{108}$. Bu bağlamda örneğin AB içerisinde Yunanistan, Slovenya ve Birleşik Krallık gibi bazı ülkeler medeni ve ticaret hukukundan doğan uyuşmazlıkları arabuluculuğa elverişli sayarken, Almanya ve Çek Cumhuriyeti gibi diğer bazı ülkeler kanunlarda açıkça kapsam dışında bırakılmamış tüm uyuşmazlıkları arabuluculuğa elverişli saymışlardır ${ }^{109}$.

Ülkemiz uygulamasında ise, HUAK'ın 1(2)'nci maddesi “Bu Kanun yabancılık unsuru taşıyanlar da dâhil olmak üzere, ancak tarafların üzerinde serbestçe tasarruf edebilecekleri iş veya işlemlerden doğan özel hukuk uyuşmazlıklarının çözümlenmesinde uygulanır..." demek suretiyle tarafların üzerinde serbestçe tasarruf edemeyeceği konuları açık bir şekilde kapsam dışında bırakmıştır. Ticari uyuşmazlıkların büyük bir kısmı tarafların üzerinde serbestçe tasarruf edebilecekleri

103 Tanriver, (Kamu Düzeni), s. 477.

104 Schnabel, s. 54.

105 Chong/Steffek, s. 475.

106 Schnabel, s. 54.

107 Schnabel, s. 54 .

108 Öztürk, s. 230.

$109 \mathrm{AB}$ ülkeleri içerinde hangi tür uyuşmazlıkların arabuluculuğa elverişli olduğu konusunda daha ayrıntılı bilgi için Bkz. https://e-justice.europa.eu/content_mediation_in_member_states-64-en.do son erişim tarihi 10 Ekim 2019. 
konulara dairdir. Ancak sulh anlaşması ticari konuların ötesinde bazı hususları ele alabilir veya tarafların üzerinde serbestçe tasarrufta bulunamayacağı mevzuları çözüme kavuşturmayı amaçlayabilir. Bu halde anlaşmanın ticari konuların ötesinde, örneğin ceza yargısına veya idari yargının görev alanına giren konuları ele alması durumunda bu kısımlara ilişkin icra edilebilirlik talebi reddedilecektir ${ }^{110}$. Keza iflas tarafların üzerinde serbestçe tasarruf edecekleri bir alan olmayıp, taraflardan birisinin iflasını öngören bir anlaşmanın icra edilebilirliği talebi de reddedilecektir ${ }^{111}$.

\section{Singapur Sözleşmesi'nin Yürürlüğe Girişi ve Uygulanmamasına Iilişkin Çekince Koyma İmkanı}

Singapur Sözleşmesi’nin 14'üncü maddesi gereğince Sözleşme, üçüncü onay, kabul, uygun bulma veya katılma belgesinin Sözleşme’nin 10 maddesi ile tevdi makamı (depositary) olarak atanan Birleşmiş Milletler Genel Sekreteri’ne tevdi edilmesinden sonra altı ayın geçmesi üzerine yürürlüğe girecektir ${ }^{112}$. Üçüncü devletten sonra onay, kabul, uygun bulma veya katılma belgesini tevdi eden devletler bakımından ise Sözleşme söz konusu tevdi belgesinin verilmesinden sonra altı ayın geçmesi üzerine yürürlüğe girecektir ${ }^{113}$. Halihazırda henüz hiçbir ülke Sözleşmeyi onaylamamış olmakla birlikte, imzacı ülke sayısının fazla oluşu ve müzakerelerin kısa bir zaman içerisinde tamamlanmış olması Sözleşme’nin kısa zaman içerisinde yürürlüğe gireceğini göstermektedir ${ }^{114}$.

Öte yandan, Sözleşmeyi onaylayan devlet sulh anlaşmasının yapıldığı devlete bağlı olmaksızın, diğer bir anlatılma karşılıklılık olmadan, uluslararası nitelikteki sulh anlaşmalarını Sözleşmede öngörülen koşulları taşımak kaydıyla tanıyacak ve icra edecektir. Esasen yukarıda ifade edildiği üzere, New York Sözleşmesi'nden farklı olarak Singapur Sözleşmesi sulh anlaşmalarına bir milliyet atfetmemiştir. Arabuluculuk sonucunda oluşan sulh anlaşmalarının milliyetinin olmamasının doğal sonucu olarak, milliyete bağlı karşılıklılık aramak da anlamsız kalacaktır.

Diğer taraftan, Singapur Sözleşmesi’nin 8'inci maddesi taraf Devletlere Sözleşme’nin kendileri bakımından uygulanmaması konusunda iki tür çekince koymalarına izin vermiştir. İlk çekince türü Sözleşme’nin 8 (1)(a) hükmü uyarınca konulabilecektir ${ }^{115}$. Buna göre taraf Devlet, kendisinin veya devlet organlarının veyahut devlet organı adına hareket eden bir kişinin taraf olduğu sulh anlaşmalarınaSingapur Sözleşmesi’nin uygulanmayacağını açıklayabilir.Öteyandan, Sözleşme’nin

110 Özel, s. 53.

111 Akıncı, s. 400; Özel, s. 45.

112 Singapur Sözleşmesi, m. 14 (1); Singapur Sözleşmesi’nin uluslararası anlaşma statüsü gereği ülkemiz bakımından yürürlüğe girmesi için Anayasa’nın 90’nncı maddesi uyarınca kabul edilecek bir uygun bulma kanunu sonrasında onaylanması gerekecektir. Onaylama ile birlikte, Sözleşme ülkemiz bakımından kanun hükmünde olmak üzere yürürlüğe girecektir.

113 Singapur Sözleşmesi, m. 14 (2).

114 Singapur Sözleşmesi’nin imza, onay, sonradan katılım ile ilgili son durumu için Bkz. https://uncitral.un.org/en/ texts/mediation/conventions/international_settlement_agreements/status, son erişim tarihi 11 Ekim 2019.

115 Belarus Singapur Sözleşme’sini imzalarken söz konusu hükme istinaden çekince koymuştur. Bkz. https://uncitral. un.org/en/texts/mediation/conventions/international_settlement_agreements/status son erişim tarihi 13 Ekim 2019. 
hangi ölçüde uygulanmayacağı da yapılan çekinceye ilişkin Deklarasyonda belirtilmelidir ${ }^{116}$. Bu bağlamda, devlet veya devlet organlarının taraf olduğu sulh anlaşmalarının tümü çekince kapsamına alınacağı gibi, belli kategoride veya yalnıza belli kişilerin imzaladığı veyahut belli kurumların taraf olduğu anlaşmalara Sözleşme’nin uygulanmayacağı açıklanabilir ${ }^{117}$. Kısaca, söz konusu hükümden Sözleşme’nin çekince konulmadığı sürece devletin taraf olduğu sulh anlaşmaları bakımından da uygulanacağı, konulması halinde ise ancak yapılan Deklarasyonda belirtilen koşullar çerçevesinde uygulanacağı anlaşılmaktadır.

Sözleşmeye konulacak ikinci çekince türü Sözleşme’nin 8(1)(b) hükmünde düzenlenmiştir ${ }^{118}$. Anılan hükme göre taraf Devlet Sözleşme’nin ancak arabuluculuk sonucunda ortaya çıkan sulh anlaşması taraflarının Sözleşme’nin uygulanmasını kararlaştırmaları halinde uygulanacağını açıklayabilir. Taraf Devletçe konulacak bu çekince, sulh anlaşması taraflarının Singapur Sözleşmesi’nin kendileri bakımından uygulanmayacağını kararlaştırmalarından farklı bir durumu ifade eder. Yukarıda açıklandığı üzere, sulh anlaşması tarafları kendi iradeleri ile Singapur Sözleşmesi'nin kendi anlaşmaları bakımından uygulanmayacağını kararlaştırabilirler $(o p t \text {-out })^{119}$. Burada sözü edilen çekince ise taraf Devletin koyduğu ve Singapur Sözleşmesi’nin ancak sulh anlaşması taraflarının Sözleşme’nin uygulanmasını kararlaştırmaları halinde uygulanacağını açıklamasına yöneliktir ${ }^{120}$.

Öte yandan, Sözleşme taraf Devletlere yukarıda bahsedilen çekinceleri koyma zamanı bakımından geniş bir esneklik tanımıştır. Buna göre taraf Devletler bahse konu çekinceleri her zaman koyma imkanına sahiptirler. İlgili Devletin çekinceyi Sözleşme’nin imzalanması veya onaylanması aşamasında koyması halinde çekince Sözleşme’nin yürürlüğe girmesi ile birlikte hüküm ifade edecekken, daha sonra konulan çekinceler, çekincenin konulmasından sonraki altıncı ayın sonunda geçerlilik kazanacaktır. Diğer yandan, daha önce konulan çekinceler sonradan kaldırılabilir. Şu kadar ki; çekincenin kaldırılmasına ilişkin Bildirim de yapılmasından sonraki altıncı ayın sonunda geçerli hale gelecektir. Konuyla ilgili son olarak İran ve Belarus dışında bahse konu hükümlere dayanarak çekince koyan devlet olmadığg vurgulanmalıdır.

\section{SONUÇ}

Singapur Sözleşmesi'nin yürürlüğe girmesi ile birlikte, arabuluculuk yoluyla uluslararası ticari uyuşmazlıkları çözen sulh anlaşmaları, taraflar arasında yapılan alelade bir sözleşmeden çıkıp, Sözleşme tarafı ülkelerde dava veya tahkim gibi başka bir sürece konu edinmeksizin tanınabilme ve icra edilebilme imkanına kavuşacaktır. Bu anlamda Singapur Sözleşmesi kapsamına giren sulh anlaşmaları önemli bir uluslararası hukuki vasıf kazanacaktır.

116 Chong/Steffek, s. 460.

117 Chong/Steffek, s. 460-461.

118 İran Singapur Sözleşme’sini imzalarken söz konusu hükme istinaden çekince koymuştur. Bkz. https://uncitral.un.org/ en/texts/mediation/conventions/international_settlement_agreements/status son erişim tarihi 13 Ekim 2019.

119 Abramson, s. 373; Schnabel, s. 56.

120 Abramson, s. 373; Chong/Steffek, s. 460. 
Singapur Sözleşmesi sulh anlaşmalarına tanınması ve icrası konusunda New York Sözleşmesi’nin sistematiğini takip etmiştir. İki sözleşme arasındaki büyük benzerliklere rağmen, sözleşmelerde kullanılan terimler, terimlere yüklenen anlamlar arasında farklılıklar da bulunmaktadır. Keza hakem kararlarına kıyasla, sulh anlaşmalarının tanınması ve icrasının tabi olduğu tutulduğu şartlar ile icra edilebilirlik talebinin reddi sebeplerinin ele alınışı biçiminde de farklılıklar bulunmaktadır. Sözleşme arabuluculuk süreci ve süreç sonucunda oluşan sulh anlaşmalarının mahiyetinden kaynaklanan bu farklıkları başarılı bir şekilde ele almış ve sulh anlaşmalarının basit ve düzenlenmiş bir usul uyarınca bağlayıcı ve uygulanabilir olmasını amaçlamıştır. Sözleşmeye imzacı olan ülke sayısının fazlalığı ve müzakerelerin kısa bir zaman içerisinde tamamlanmış olması Sözleşme’nin başarısına işaret etmektedir.

$\mathrm{Bu}$ doğrultuda, Singapur Sözleşmesi’nin sulh anlaşmalarının tanınması ve icrası açısından önemli bir uluslararası aşamayı teşkil ettiği söylenebilir. Sözleşme’nin küreselleşme ile birlikte muazzam boyutlara ulaşan uluslararası ticaret sisteminin ihtiyaç duyduğu hız, ucuzluk, esneklik ve öngörülebilirlik ihtiyacını karşılayabileceği değerlendirilmektedir. Kısa zamanda yürürlük kazanması beklenen Sözleşme; bir yandan arabuluculuk yolunun uluslararası ticari uyuşmazlıkları çözmek bakımından daha sık başvurulan bir yöntem olmasını sağlayacak, diğer yandan da uluslararası ticari ilişkilerin gelişmesine katkıda bulunacaktır.

Singapur Sözleşmesi’nin ilk imzacılarından olan Türkiye’nin ise Sözleşme ile getirilen sisteme hazır olduğu değerlendirilmektedir. Nitekim, Türkiye 2012 yılında HUAK’’ kabul ederek uyuşmazlıkların arabuluculuk yoluyla çözümü konusunda büyük bir aşama kaydetmiştir. HUAK’ın arabuluculuk süreci sonucunda oluşan anlaşmalara icra edilebilirlik şerhi alma imkanını tanıması, Singapur Sözleşmesi ile getirilen anlayışın Türk hukuk uygulamasına çoktan girdiğini göstermektedir. Bu bağlamda Sözleşme’nin Türkiye tarafından onaylanarak yürürlüğe konulması yerinde olacaktır.

\section{KAYNAKÇA}

Abramson H., New Singapore Convention on Cross-Border Mediated Settlements: Key Choices, Mediation in International Commercial and Investment Disputes, Eds. Titi C./ FachGomez K., Oxford University Press, 2019.

Akıncı Z., Milletlerarası Tahkim, Vedat Yayıncılık, 2016.

Arat T., Yabancı İlamların Tanınması ve Tenfizi, AÜHFD, Cilt 21 Sayı 1-4, 1964, s. 421-527.

Aygün M ., Yabancılık Unsurunun Mahiyeti ve Yargılamadaki Rolü, Dokuz Eylül Üniversitesi Hukuk Fakültesi Dergisi, 2014, s. 1025-1066.

Can H./ Tuna E., Milletlerarası Usul Hukuku, 2. Baskı, Adalet Yayınevi, 2019.

Çalışkan Y., Uluslararası Satım Hukukunda Kanunlar İhtilafı Meseleleri, Beta Yayınları, 2014.

Çelikel A./Erdem B. B., Milletlerarası Özel Hukuk, 15. Baskı, Beta Yayınları 2017.

Chong S./ Steffek F., Enforcement of International Settlement Agreements Resulting From Mediation Under The Singapore Convention - Private International Law Issues in Perspective, Singapore Academy of Law Journal. 31, (Special Issue), 2019, s. 448-486.

Chua E., The Singapore Convention on Mediation - A Brighter Future for Asian Dispute Resolution, Asian Journal of International Law, 2019, s. 195-205. 
Claxton J., The Singapore Convention: Mediation in a New York State of Mind, https://ssrn.com/ abstract $=3416116$.

Dayınlarlı K. Hakem Kararlarına Etkisi Bakımından Millî-Milletlerarası Kamu Düzeni, http://www. dayinlarli.gen.tr/wp-content/uploads/2018/03/intes2003.pdf son erişim tarihi 30 Kasım 2019.

Doğan V., Milletlerarası Özel Hukuk, 5. Baskı, Savaş Yayınevi, 2019.

Erdoğan E., Milletlerarası Arabuluculuk Anlaşma Belgelerinin İcrasına İlişkin BM Sözleşmesinin (Singapur Sözleşmesi) Değerlendirilmesi, Arabuluculuğun Geliştirilmesi Uluslararası Sempozyumu, 6-7 Aralık 2018, s 189-202.

Güllüoğlu Altun Y., Aile Arabuluculuğu (Sisteme Genel Bakış), Prof Dr. Hüseyin Hatemi’ye 80. Yıl Armağanı, Edt. Güllüoğlu Altun Y, Onikilevha Yayınları, 2018, s. 477-514.

Hioureas C. G., The Singapore Convention on International Settlement Agreements Resulting from Mediation: A New Way Forward?, 37 Berkeley J. Int'l Law, 2019, s. 215-224.

International Mediation Institute, GPC Series 'Cumulated Data Results, https://www.globalpound.org/ wp-content/uploads/2017/11/2017-09-18-Final-GPC-Series-Results-Cumulated-Votes-from-theGPC-App-Mar.-2016-Sep.-2017.pdf son erişim tarihi 3 Ekim 2019.

İstanbul Tahkim Merkezi (İSTAC) Tahkim ve Arabuluculuk Kuralları, https://istac.org.tr/wp-content/ uploads/2016/01/ISTANBUL-TAHKIM-MERKEZİ-TAHKİM-ve-ARABULUCULUKKURALLARI.pdf, son erişim tarihi 10 Ekim 2019.

Nomer E. Devletler Hususi Hukuku, 22. Bası, Beta Yayınları, 2017.

Özdemir Kocasakal H., Elektronik Sözleşmeden Doğan Uyuşmazlıkların Çözümünde Uygulanacak Hukukun ve Yetkili Mahkemenin Tespiti, İstanbul, 2003.

Ovacık M., İngilizce-Türkçe Hukuk Sözlüğü, 3. Baskı, Banka ve Ticaret Enstitüsü, 2000.

Özekes M., Pekcanıtez Usul Medeni Usul Hukuku, 15. Bası, İstanbul, 2017

Proposals For Amendment Of The ICSID Rules, Working Paper \#3, Volume 1 English August 2019, https://icsid. worldbank.org/en/Documents/WP_3_VOLUME_1_ENGLISH.pdf, son erişim tarihi 3 Ekim 2019.

Özbek M. S., Alternatif Uyuşmazlık Çözüm Yolu, 2. Baskı, Yetkin Yayınları, 2016, (Alternatif Uyuşmazlık Çözüm Yolu).

Özbek, M. S., Arabuluculuk Sonunda Düzenlenen Anlaşma Belgesine İcra Edilebilirlik Şerhi Verilmesinde Görevli ve Yetkili Mahkeme, Başkent Üniversitesi Hukuk Fakültesi Dergisi, Cilt: 3, Sayı: 2, Temmuz 2017, s. 69-85 (İcra Edilebilirlik).

Özel S., Milletlerarası Ticari Tahkimde Kanunlar İhtilafı Meseleleri, Legal Yayıncılık, 2008.

Özkan I./Tütüncübaşı U., Uluslararası Usul Hukuku, Adalet Yayınevi, 2017

Özsunay E. "Arabuluculuk Sonucunda Yapılan Uluslararası Sulh Anlaşmaları Hakkında Birleşmiş Milletler Sözleşmesi”: Singapur Arabuluculuk Sözleşmesi Türk Hukukuyla Uyumu Bakımından Bir Değerlendirme, İstanbul Barosu Dergisi, Cilt: 93, Sayı: 3, 2019, s. 31-49.

ÖZTÜRK, N., Arabuluculuğun Milletlerarası Özel Hukuk Boyutu: Genel Bakış, Banka ve Ticaret Hukuku Dergisi, Cilt: 31, Sayı: 2, 2015, Sayfa: 203-254

Sargın, F./Erten, R., MÖHUK Hükümleri Dairesinde Tanımanın Hukuki Niteliği, Usûlü ve Karşılaşılan Bazı Sorunlar: Yeni Bir Düzenleme Yapma Gereği, Uluslararası Ticaret ve Tahkim Hukuku Dergisi, İstanbul 2014, C.3, S.2, s. 37-136.

Schnabel T.,The Singapore Convention on Mediation: A Framework for the Cross-Border Recognition and Enforcement of Mediated Settlements, 19Pepp. Disp. Resol. L.J.1, 2019, s. 15-60.

Silvestri E., The Singapore Convention on Mediated Settlement Agreements: A New String to the Bow of International Mediation?, Revista Eletrônica de Direito Processual - REDP. Rio de Janeiro. Ano 13. Volume 20. Número 2, 2019, s. 192-200. 
Strong, S.I., Beyond International Commercial Arbitration? The Promise of International Commercial Mediation. 45 Washington University Journal of Law and Policy, 2014, s.11-39.

Sussman E., The Singapore Convention Promoting the Enforcement and Recognition of International Mediated Settlement Agreements, ICC Dispute Resolution Bulletin, Issue 3, 2018, s 42-54.

Şanlı C., Uluslararası Ticari Akitlerin Hazırlanması ve Uyuşmazlıkların Çözüm Yolları, 7. Bası, Beta Yayınları, 2019.

Şanlı C./ Esen E./ Ataman-Figanmeşe İ., Milletlerarası Özel Hukuk, 7. Bası, Beta Yayınları, 2019.

Tanrıver S., Hukuk Uyuşmazlıkları Bağlamında Alternatif Uyuşmazlık Çözüm Yolları ve Özellikle Arabuluculuk, TBB Dergisi, 2006, Sayı 64, s. 151-177 (Arabuluculuk).

Tanrıver, S ., Yabancı Hakem Kararlarının Türkiyede Tenfizi Bağlamında Kamu Düzeninin Etkisi, Milletlerarası Hukuk ve Milletlerarası Özel Hukuk Bülteni Cilt 17, 2011. s. 467-492 (Kamu Düzeni).

Tiryakioğlu B. Taşınır Mallara İlişkin Milletlerarası Unsurlu Satım Akitlerine Uygulanacak Hukuk, Ankara Üniversitesi Hukuk Fakültesi Yayınları, 1996.

Türkiye Cumhuriyeti Adalet Bakanlığı, Arabuluculuk Daire Başkanlığı, Temel Arabuluculuk Eğitimi Katılımc1 Kitabı, 2019.

Topaloğlu M., Tahkimde Kamu Düzenin Etkisi, International Conference on Eurasian Economies, 2013, s. 890-893.

UNCITRAL Model Law on International Commercial Mediation and International Settlement Agreements Resulting from Mediation, 2018 (amending the UNCITRAL Model Law on International Commercial Conciliation, 2002) (Model Kanun), https://www.uncitral.org/pdf/english/ commissionsessions/51st-session/Annex_II.pdf son erişim tarihi 8 Ekim 2019.

UNCITRAL Press Release, Treaty event produces new signatories for the United Nations "Singapore Convention on Mediation", http://www.unis.unvienna.org/unis/en/pressrels/2019/unisl282.html son erişim tarihi 3 Ekim 2019.

United Nations General Assembly, A/RES/73/198, para 5. https://undocs.org/en/A/res/73/198 son erişim tarihi 3 Ekim 2019 UNCITRAL Press Release, Treaty event produces new signatories for the United Nations "Singapore Convention on Mediation", http://www.unis.unvienna.org/unis/en/ pressrels/2019/unisl282.html son erişim tarihi 3 Ekim 2019.

Vanisova V., Current Issues in International Commercial Mediation: Short Note on the Nature of Agreement Resulting from Mediation in the Light of the Singapore Convention, Charles University in Prague Faculty of Law Research Paper No. 2019/II/5, 2019, https://ssrn.com/abstract=3413560 or http:// dx.doi.org/10.2139/ssrn.3413560, Erişim Tarihi 16 Ağustos 2018.

Yarar G., Milletlerarası Özel Hukukta Arabuluculuk, On İki Levha Yayıncılık, 2019.

Yaşa Y, İngilizce-Türkçe/ Türkçe-İngilizce Hukuk Terimler Sözlüğü, Beta, 6. Bası.

Zeller B./ Trakman L., Mediation and Arbitration: The Process of Enforcement 201) Uniform Law Review 1; UNSW Law Research Paper No. 19-43, 2019, s. 1-19.

\section{Elektronik Kaynaklar}

https://eur-lex.europa.eu/

https://e-justice.europa.eu/

https://iccwbo.org/

http://www.cietac.org/

https://uncitral.un.org/

https://www.wipo.int/ 